\title{
VICENTE HUIDOBRO EN VANGUARDIA
}

Permítanme que les considere a ustedes, los reunidos aquí en la memoria del poeta extraordinario que fue y sigue siendo Vicente Huidobro, como una especie de tribunal académico llamado a pronunciar un importante veredicto. $Y$ que al usar de la palabra ante este tribunal lo haga algo así como testigo de la defensa de quien, desde 1921 hasta su fallecimiento, fue uno de los cuatro o cinco amigos personales y artísticos más dilectos de mi vida. Me propongo, pues, no desperdiciar la oportunidad de contribuir a sentar las bases de una comprensión equilibrada del poeta chileno frente a las incomprensiones que padeció en su existencia y en especial a partir de su muerte.

Podrá argüirse, no sin cierta verosimilitud, que él mismo fue el principal arquitecto de la falta de consideración de que fue víctima. Psicológicamente no es posible ingresar en el cercado de las letras con aires conquistadores y derribando las normas establecidas sin provocar de rechazo los desaires, cuando no las iras de sus congéneres. Que así, movido por un impulso de esa naturaleza, desembarcó Vicente Huidobro en Europa, dispuesto a conquistar la conciencia del Viejo Mundo a favor de la del Nuevo que sentía dentro de sí. El mismo confesaría:

Yo vine a Madrid en 1916 y me fui a ver a Rafael CansinosAsséns para tratar de formar un grupo. Cansinos me dijo que era imposible. Hablamos varias tardes y me fui a París.

Nunca desde entonces cejó Huidobro en su intento de atraer hacia sí y hacia sus teorías sobre la esencia y la misión del poeta el interés, ya que no la devoción, de sus lectores en Francia, España, Alemania, Suecia... e Hispanoamérica, por supuesto. Se comportaba en cierto modo como una especie de caudillo solitario, como una cabeza de cometa en procura de sus séquitos caudales. Todavía en 1939 Vicente sostenía sus convicciones diciendo en una entrevista de prensa poco conocida: «La 
poesía contemporánea empieza en mí». Declaraciones de esta índole no eran evidentemente las más apropiadas para ganarse el respeto de las sensibilidades, por lo común tan susceptibles, de los poetas y sus círculos. Mas la reacción de sus fallidas huestes llegó a extremos desconcertantes.

He aquí unas muestras: Dámaso Alonso, en su libro Poetas españoles contemporáneos, donde se ocupa del ultraísmo, no se toma la molestia de mencionar el nombre de Huidobro, su promotor, «el que trajo las gallinas», al decir de González Ruano. Ramón Gómez de la Serna, en su libro Ismos, de 1947, sigue los pasos del actual presidente de la Academia Española. Guillermo de Torre, una vez extinguidos sus entusiasmos iniciales, le declaró una guerra sorda, sólo a ratos disfrazada, cuando estimó suficientemente establecida su superioridad. En la revista España apareció el siguiente juicio, más bien autosalomónico, de Antonio Espina: «El tan cacareado poeta transatlántico y bilingüe Vicente Huidobro es una calamidad. Ni es nuevo, ni es original, ni escribe bien». Henríquez Ureña le nombra como poeta de baja categoría. Me consta, por haberlo oído de sus labios, que Alfonso Reyes abundaba en un juicio similar. Borges, por su parte, no se ha privado de minimizarlo, quizá para empinarse a sí mismo sobre el pedestal, oportunamente ensalzado, de quien fue el mantenedor inicial del chileno, Rafael CansinosAsséns.

Sobre estos fundamentos no es del todo extraño, aunque sí sea vergonzoso, que en el libro de divulgación de J. M. Cohen, publicado en Inglaterra en 1959, y cuatro años después en los Breviarios del Fondo de Cultura de México, cuyas páginas se ocupan de todos los poetas hispanoparlantes desde Antonio Machado y Juan Ramón Jiménez, se habla mucho de Neruda, de García Lorca, de Alberti, Aleixandre, Altolaguirre, Guillén, Molinari, Eliot, Breton, Octavio Paz, etc., ni de pasada se le nombre a Huidobro. ¿Será todo ello culpa suya, de su calidad supuestamente despreciable, o será defecto de la crítica más sensible a ciertos convencionalismos decorosos que a las sustancias poéticas?

Pero veamos otro caso, éste francés, clamante al cielo. El distinguido crítico de arte Maurice Raynal, que había sido quien presentó la exposición de poemas pintados de Huidobro en el París de 1922, cuando años más tarde reseña detalladamente los acontecimientos artísticos universales año por año y en el párrafo correspondiente a 1917 se refiere a la revista Nord-Sud, asienta: «En París, Pierre Reverdy funda la revista Nord-Sud con la colaboración de Apollinaire, Aragon, Breton, Max Jacob y Soupault». La ausencia total del nombre de Huidobro, que contribuyó ese año a dicha publicación con doce poemas -tantos como 
Reverdy - y la intromisión de los futuros surrealistas, resulta quizá algo menos chocante al advertir a la vez la ausencia de Paul Dermée, quien a la sombra de Apollinaire había constituido, con Reverdy y Huidobro, el terceto más distinguido de la concreción estética de Nord-Sud. Interprételo cada cual a su manera, mas sin perder de vista que ni Dermée ni Huidobro eran franceses (ni pintores).

Desde luego, Vicente Huidobro era inducido compulsivamente a manifestar su ansia voluntariosa de asumir un puesto dirigente en varios aspectos, mas sobre todo en cuestiones de poesía y literatura. $\mathrm{Ni}$ se privaba de intentarlo en el centro de la cultura occidental que significaba París. Pretendía ser el primero, con anticipación a los demás en lo relativo al valor de la poesía moderna, en teoría y en la práctica. Por mi parte creo que no andaba lejos de la verdad cuando sostenía en la entrevista mencionada que "la poesía moderna empieza en mí». Pero me pregunto, ¿lo creía así por capricho vanidoso, sin otro fundamento que la ambición de pavonearse en escena, o porque en realidad era constitutivamente el primero? Convencido estoy personalmente de no engañarme al sostener que su ímpetu irreflexivo se debía a su naturaleza psicosocial misma y, por tanto, a su destino de precursor; al destino de quien camina delante, preparatoriamente, en el desarrollo creador de la cultura como un todo orgánico. Lo cierto es que, por serle ello consustancial, reaccionaba enérgicamente contra quienes al desconocer el valor trascendental de la poesía, tal como se concebía en él, atentaban contra algo que le era muy sagrado, a la vez que siendo algo muy consustantivamente suyo atentaban contra él. Entiendo, como digo, que era precursor. Pero creo también que, al reaccionar con exceso en el medio a que pertenecía, era juguete de un espíritu infantil que no acertaba a dominar. Su intuición precursora era real, pero la hojarasca en que a veces se envolvía al manifestarse era propia de ese momento del proceso juvenil en que el adolescente se encara con la voluntad de ser y cuyas formas circunstanciales indomeñadas van atenuándose hasta que con el crecimiento se domestican.

Vicente salió del medio en que germinó su personalidad con el impulso de un proyectil obstinado en perforar los obstáculos que le separaban del ideal que se había forjado de sí mismo o que las circunstancias habían establecido en él Sus confesiones en Pasando y pasando, en Vientos contrarios y en sus Manifiestos evitan cualquier incertidumbre al respecto. La seguridad de su impudor es impresionante. Costara lo que costara tenía que llegar a ser persona de excepción, engreída como tal desde el comienzo. Su condición de hijo mimado y los cuantiosos bienes familiares le eran de mucha ayuda para perseguir el logro de sus 
ambiciones. Pero la fantasía en esto, más que la imaginación, le jugaba a veces malas partidas. Cuando no podía alcanzar sus pretensiones de altura por las buenas, no desdeñaba recurrir a representarlas, o sea, a servirse de la ficción. Podía simular algunas cosas, alterar la realidad, predatar ingenuamente sus escritos, mentir si lo estimaba conveniente para mantener el orgullo constitucional de su egolatría. Para el espíritu académico esa manera de conducirse no es seria. Por tales declives fue sembrando motivos para su descrédito entre aquellas otras personas que, inducidas asimismo por sus ambiciones literarias, se complacían en disminuir su talento. Esto le sucedió en España, en Francia y con seguridad en Chile y Argentina. ¿Actuaban así frente a él tales personas por mero arribismo literario, disgustadas por la actitud ensoberbecida de Vicente y por el brillo de sus proposiciones y cualidades competitivas o porque en realidad desdeñaban sus obras no distinguiendo sus cualidades poéticas de las del entorno adocenado? Me hago esta prengunta pensando particularmente en Guillermo de Torre, que manifestó sus inclinaciones arribistas en circunstancias diversas y que en España fue su enemigo más injusto, con repercusiones en Francia y otros países merced a sus Literaturas europeas de vanguardia. Siempre que he pensado en ello he llegado a la conclusión de que Guillermo no entendía en realidad de poesía en cuento actividad creadora. Estaba enterado, por cierto; sabía muchas cosas. Pero carecía de imaginación. El acento positivo de su personalidad gravitaba sobre la memoria, en cuya virtud llegó a crearse una bonísima erudición en ciertos niveles, que manejaba con soltura. Pero en el modo como atacaba a Vicente, cuando entre otras muchas cosas trataba de demostrar la dependencia de las metáforas huidobrianas de las de Herrera Reissig, patentizaba que su percepción de los aspectos esenciales que se debatían entonces era nula. Por ser él y sus amigos ultraístas sordos a esos valores radiactivos, por decirlo así, que Vicente desplegaba, se explica la enemistad que concibieron contra el mismo.

Concretamente: entre los ejemplos que para demostrar la dependencia de la poética de Huidobro de la de Herrera Reissig traía a colación Guillermo de Torre en su libro, figuraba la siguiente: la respiración del pecho de una dama le inducía a Herrera a compararla, según mi recuerdo, al movimiento del mar, símil tan perfectamente descriptivo como antropomorfo. En cambio, los versos de Huidobro, extraídos por el crítico ultraísta del poema «Océan ou dancing», dicen así:

Tout au loin tu tiens ton coeur

Comme on tient une fleur

Mais le rythme de ta poitrine est dans la mer

Et les vagues sont chaudes du rythme de ton coeur. 
La realidad de la naturaleza aparece transfigurada en estos versos. No es el seno de una mujer de carne y hueso lo que se asocia comparativamente con el vaivén marino, como podían haberlo hecho millares de poetas tradicionales. Son las olas del océano las que están calientes a causa del ritmo del corazón de una entidad cósmica, capaz de mantener en su mano al poniente como una flor a lo lejos. De la banalidad de una dimensión lineal, de superficie, el poeta nos ha transferido creadoramente a la sublimidad cósmica del universo sin que la sensibilidad del crítico acuse la diferencia entre antropomorfismo vulgar y panteísmo sublime. En suma, la imaginación poética ha sido capaz de operar ante nuestros sentidos, mediante los elementos de la naturaleza, una transfiguración ontológica. ¿Y qué otro poeta (preguntamos entre paréntesis) ha logrado expresarse en un idioma de parecido poder sintético, lindante con la sobrenaturalidad de algo así como el eterno femenino?

Para ilustrar aún mejor estos episodios negativos de la crítica, así como para informar al Simposio de algunos aspectos de mi experiencia personal de participante de la vanguardia española y de mis relaciones con Huidobro, voy a referirles cuándo, cómo y por qué me sentí durante largos años admirador sin reticencia de Vicente, considerándolo como el iniciador del movimiento moderno en lengua española y con el que a mi juicio no podían competir los franceses, así se llamaran Reverdy, Dermée y compañía, sin excluir del conjunto al mismo Apollinaire.

Nos situaremos en 1919. Yo vivía en una ciudad vasca y jesuítica, Bilbao. Desde los doce años escribía versos espontáneamente, aunque sin mayores entusiasmos, porque los horizontes de mi medio estaban tapiados a piedra y lodo. Mantenía una correspondencia activa sobre asuntos poéticos con Gerardo Diego como condiscípulos que habíamos sido en la Universidad de Deusto. Yo venía pugnando en mi interior contra una atrofia incomodísima que me había impuesto el medio familiar y social, de la que me daba cuenta, buscando oscuramente en la poesía una especie de puerta de salvación, y aspirando a eliminar cuanto me separaba de lo que lejanamente sentía ser la Vida, con mayúscula.

Gerardo había pasado unos meses en Madrid preparándose para sus oposiciones. $\mathrm{Y}$ al regresar a su casa de Santander, se detuvo veinticuatro horas en Bilbao. Era el 2 de mayo precisamente. Traía novedades. Se había enterado en el Ateneo de Madrid por Eugenio Montes, uno de sus compañeros, de que acababa de surgir un movimiento moderno y revolucionario en poesía, el Ultraísmo. Traía consigo un ejemplar de la revista sevillana Grecia, núcleo focal del movimiento. Y también traía escritos a mano tres poemas de Vicente Huidobro, que acababa de copiar del libro Poemas árticos que le había prestado Montes. 
Me impresionó la novedad en tal forma que a partir de ese día empecé a sentirme otro. El contenido de Grecia era interesante por su información nacional e internacional y en cuanto a los fines que perseguía. Y hasta a veces era chistoso. Pero los poemas de Huidobro me resultaron decisivos. Les diré por qué. Eran tres: «Luna», «Adiós» y un tercero de cuya identidad no estoy muy seguro.

Aunque hoy pueda parecer extraño, el poemita «Luna» me conmovió. Decía así:

Estábamos tan lejos de la vida
Que el viento nos hacía suspirar
LA LUNA SUENA como UN RELOJ
Inútilmente hemos huido
El Invierno cayó en nuestro camino
Y el pasado lleno de hojas secas
Pierde el sendero de la floresta
Tanto fumamos bajo los árboles
Que los almendros huelen a tabaco
Media noche

Sobre la vida lejana

Alguien llora

Y la luna olvidó dar la hora

$\mathrm{Su}$ lectura me sumió en una atmósfera de ultramundo. Sentía su realidad como de extrema lejanía, coincidente sin duda con mi estado psíquico y quizá por ello no del todo ajeno a mi conciencia personal. No se describía en esos versos una situación fuera de lo común, sino que se la plantaba vívidamente, aquí no más, de golpe, mediante un plural que en algún modo parecía concernirnos. LA LUNA SUENA COMO UN RELOJ. Produjo en mí esta sentencia algo así como un traumatismo poético. Se construía la frase sobre un adverbio de modo, como un símil cualquiera, pero dentro de un ámbito como de campana neumática, sin tiempo ni lugar, que presuponía otra especie de existencia, afirmada sobre símbolos extraños a la experiencia humana. No se trataba, sin embargo, de un estado mental, literariamente abstracto, sino de un hecho correspondiente al mundo concreto de nuestros sentidos biológicos. La luna suena; se la oye, he ahí lo traumáticamente fenomenal. Su comparación con el reloj, a la vez que corroburadora del enunciado en sí, era meramente adjetiva, aludiendo tal vez al parecido visual del disco plenilunar a la esfera iluminada de un reloj de torre. Lo sustantivo era que la luna, lo absolutamente silencioso, sonase como con tiempo y vida propios, cosa que implicaba una transfiguración, distanciando el fenó- 
meno de nuestra realidad de seres humanos proyectándonos a otra vivencia del cosmos.

La afirmación subsiguiente era también perturbadora, en cuanto que el haber fumado excesivamente hasta enrarecer y oscurecer la atmósfera hacía que los almendros - quizá las estrellas entre la neblina-oliesen a tabaco, relegando la situación a nuestros términos más chaplinescamente vulgares. Decía por último que «en la vida lejana alguien llora», atribuyendo al sonido de la luna una emoción anónima, para añadir que, dotada de memoria como una especie de sublime ánima en pena, olvidó dar la hora. Se abismaba uno en un gran misterio parapsicológico. No se entendía racionalmente la situación, pero se sentía su profundidad vegetal, animal y sobrehumana. Era como haber pasado del anverso al reverso de la existencia.

El otro poema, «Adiós», estaba impregnado de sentimiento cósmico como el anterior, pero en forma distinta. Al despedirse de París dice el poeta, entre otras cosas:

En Notre-Dame

los ángeles se quejan

Al batir las alas nacen albas

Mas mis ojos se alejan

Todas las mañanas

Baja el sol a tu hostia que se eleva

Al oír que los ángeles se quejaban en Notre-Dame puede pensarse, mediante una doble metáfora, en las campanas convertidas en ángeles quejumbrosos. Pero al decirse que «al batir las alas nacen albas», las posibles campanas han perdido su consistencia física para convertirse en seres capaces de provocar la aparición del día con sólo agitar sus alas, cosa de la que depende la vida de la ciudad. «Mas mis ojos se alejan», continúa; se alejan como las estrellas al alborear, lo que atribuye al sujeto poético que se despide una personalidad cósmica. $Y$ añade en seguida el siguiente trastrueque inaudito en relación con el nacimiento del día y la partida de los ojos: «Todas las mañanas / Baja el sol a tu hostia que se eleva». Entre el sol y la hostia consagrada en Notre-Dame se efectúa un intercambio de calidades trascendentales. Baja el sol, como en el poniente; pero aquí, por no ser en realidad sol, en la madrugada desciende del cielo, idénticamente a Dios en la consagración sacramental. Lo que se eleva en cambio es la hostia transustanciada, convertida en sol irradiante. Si sobre estos principios deslumbradores de intercambio entre lo natural y lo sobrenatural se deja operar a la imagi- 
nación, la poesía se adueña de uno, deshaciendo el orden de las especies de costumbre para proyectarlo a una región imaginaria, indescriptible pero vivible. Creacionismo puro. Como el de una sinfonía.

Yo sentí que el universo, con sus infinitas posibilidades, se me había introducido en la cabeza, y de aquí que desde ese día mi actitud ante la actividad poética, aunque balbuceante, fuese otra.

Al mes siguiente viajé a Madrid como todos los años. Adquirí en seguida Poemas árticos en la librería Pueyo, donde no disponían de los otros libros.

Visité a Cansinos-Asséns en La Correspondencia de España. Gerardo Diego le había escrito anunciándome. Cansinos fue tan amable que me prestó Hallali, Tour Eiffel y Ecuatorial, que transcribí de inmediato. El último me produjo una impresión hondísima. Al devolverle los libros tres o cuatro días después, me preguntó Cansinos tras mi gran alabanza de Ecuatorial: "-¿Qué libro le recuerda, o con cuál lo relacionaría usted?».

Contesté sin vacilar: «-Con el Apocalipsis». Pareció sorprenderse. Quizá pensara - supuse años más tarde- en el Coup de dés, que desconocía yo por completo entonces. «-Ah, bueno..., sí» - repuso dejando la especie en el aire. En efecto, Ecuatorial se proyecta a una situación escatológica con todas sus catástrofes, Alfa y Omega, para terminar anunciando «el fin del universo». No necesito descubrir que bajo su influencia escribí Cosmopolitano, referente a la soñada ciudad cósmica.

Como recordamos ayer, los signos culturales de la mente occidental inducían a pensar y sentir aquellos años en un final de época, pero en un final, tanto como a lo ancho, a lo hondo, transmutativo. Para entender su significado, algunas de las sensibilidades más despiertas acudían a los contextos de los símbolos culturales del sistema de entendimiento del mundo en que se habían educado. Así, Rubén Darío, después de recibir al nuevo siglo el primero de enero de 1901 definiéndolo como una «locomotora que va con una presión de todos los diablos a estrellarse en no sé qué paredón de la historia y a caer en los abismos de la eternidad", había escrito cuatro años después Canto de esperanza, donde pedía a grandes gritos la venida apocalíptica del Señor. Y, sobre todo, en 1915 compuso el poema «Pax», concretamente de fin de mundo. Puro Apocalipsis con su específico "caballo blanco». Así también, entre las conciencias avizoras de Francia, Léon Bloy escribía coetáneamente su libro Au seuil de l'Apocalypse.

Creo que todos estamos de acuerdo con lo sostenido por uno de los ponentes de ayer en el sentido de que la cultura es un sistema orgánico de valores. Mas por mi parte no me siento animado a sostener, junto 
a él, que una cultura nueva se ha de lograr mediante el establecimiento de una simple organización materialista, perspectiva que, por parcial, juzgo errónea. Una cultura integrada es un sistema orgánico, o mejor, superorgánico, en el que se resuelven armónicamente los problemas materiales y los espirituales, los físicos y los metafísicos, conforme a la complejidad del ser humano. No ha existido cultura alguna en la que, a la vez que se resuelven los problemas de orden material, no proporcione a sus miembros la participación en un sistema de creencias colectivas, mágicas o religiosas, sean las que fueren, que satisfaga las ansiedades intrínsecas, espirituales, de sus individuos. De otro modo, una cultura verdaderamente materialista no pasaría de ser un cuerpo físico susceptible de adquirir inmensa magnitud, tan inmensa como puede parecerle a una hormiga la mole de un elefante; incapaz de rebasar el nivel de lo estrictamente animal. Pues bien: en virtud de que el hombre es un ser humano, no puede extrañarnos que, junto a poetas que se limitan a ensalzar las funciones animales y cuantitativas de la humanidad, existan otros más clarividentes que enfocan los aspectos espirituales, sean los que fueren. Entre la de estos últimos se ha de registrar la experiencia ciertamente sui generis, pero sin duda poético-espiritual, de Vicente Huidobro. Creo que si no se entienden estas realidades, la de la ruptura del siglo hacia 1914 y la de la renovación o transmutación de valores no sólo científicos y políticos, sino también espirituales, no es posible entender cabalmente lo que está pasando en el planeta desde entonces.

Pero dejaré esto aquí para volver a aquel momento de 1919 cuando en España acababa de asomar cabeza el ultraismo. Por indicación de Cansinos yo visité una vez -y sólo una vez- un lugar donde se reunían en aquella ocasión los ultraístas y conocí al director de Grecia, Isaac del Vando Villar, de paso en Madrid, y a algunos de sus compañeros. No pasé de ahí. No volví a tener relación ni con Casinos ni con los demás, porque su actitud no se armonizaba con la mía, inclinada a niveles más silenciosos. La casi totalidad de los poemas que aparecieron en Grecia con mi nombre se publicaron contra mi voluntad. Se los transmitió Cansinos por propia iniciativa, quien los había recibido de Gerardo Diego.

Casi excusado es decir, como cosa harto sabida, que el ultraísmo fue consecuencia del impacto que produjo la estancia de Huidobro en Madrid de julio a noviembre y su exaltación de la poesía. Fue hijo suyo natural, aunque la madre fuera de otro linaje. Todavía suele nombrarse a Ramón Gómez de la Serna entre los progenitores del ultraísmo. Sin embargo, Ramón no compuso poesía nunca, ni cultivó más campos que 
los del futurismo, con aditamentos de Jules Renard en lo que respecta a sus greguerías. Ramón se inscribe sin duda en la línea materna del ultraísmo, que fue un pronunciamiento exclusivamente poético.

La voz ultra no fue invención de Huidobro, obsesionado por el creacionismo, ni de Guillermo de Torre, bueno es repetirlo, aunque otra cosa pretenda este último, sino de Cansinos-Asséns, que intuyó el significado del lema heráldico del escudo y del destino español. Existen testimonios a granel del mismo Cansinos, de Gerardo Diego, de Xavier Bóveda, etc., e inclusive del mismísimo Guillermo de Torre. Pero la historia de la literautra abunda en vanidades deformativas de erradicación no siempre fácil.

Obligado me es volver a pronunciar aquí el nombre de Guillermo de Torre, que desde que publicó en Grecia su Manifiesto Vertical en noviembre de 1920 se constituyó en cabecilla del ultraísmo y dio rienda suelta a sus ambiciones, sin guardar el respeto debido ni a CansinosAsséns ni a Huidobro. Creo que Juan Jacobo Bajarlía tiene fundamentalmente razón al hacerle objeto de sus censuras, aunque el esquema de sus apreciaciones psicológicas no contribuya a conferirles toda la eficacia que merecen.

He de dedicar alguna atención a ciertos sucesos relacionados con lo que vengo recordando. He aquí el primero. En diciembre de 1921 volvió Vicente Huidobro a Madrid en una de sus giras a favor de lo que podría llamarse tanto «poesía redentora» como creadora. Fue en esta circunstancia cuando Gerardo Diego y yo trabamos conocimiento y relaciones duraderas con él. El día en que leyó su conferencia sobre la Poesía, el gran salón del Ateneo estaba atestado. Lo presentó Mauricio Bacarisse y se le escuchó con atención, pero con perceptible reticencia. Cierto es que en su viaje anterior Huidobro se había indispuesto hasta ruidosamente con Gómez de la Serna, con Díez Canedo y Juan Ramón Jiménez, según se comentaba, y con sus respectivos círculos. Yo salí del acto deslumbrado por los conceptos que Huidobro expuso sobre la Poesía, y creo que a Gerardo le sucedió lo propio. Pero también me sentí escandalizado. Mi impresión fue que los ultraístas estaban atizando por lo bajo la frialdad de la incomprensión, según pudo comprobarse a la salida. Ninguno de ellos estuvo en esa oportunidad en relación amistosa con Huidobro. Hacía mes y medio que se había publicado el Manifiesto Vertical de Guillermo de Torre. Como Gerardo sólo permaneció en Madrid un par de días, yo mantuve con Vicente un trato más seguido y profundo, en el que aprendí no pocas cosas importantes para las que estaba ya predispuesto por naturaleza, y nuestra amistad plantó sus primeras y definitivas raíces. 
Diré la impesión que Vicente me produjo entonces. Me pareció una persona exuberante de sincero y amistoso fervor. Su juventud se plasmaba en el entusiasmo más puro y optimista. Lo sentí poeta ciento por ciento, esto es, únicamente poeta, genial, cuya presencia irradiante podría despertar sentimientos envidiosos entre los bajos fondos y niveles, pero digno de la simpatía y admiración de los mejor dotados. Era tajantemente radical en sus juicios y opiniones, a la vez que rebosaba sabiduría novedosa ilustrada por la pintura de París, que exponía con juvenil desenfado. $Y$ sentía yo en su modo de ser y de expresarse la presencia de una especie de imaginación neomúndica, libre y abierta a horizontes amplísimos. Me mostraba las pruebas de imprenta de su libro Saisons Choisies, entre cuyos poemas me entusiasmaron realmente los últimos, «Automne regulier», "Globe-trotter» y "Océan ou dancing». Contaba que el día que compuso "Globe-trotter» le escribió un pneu a Juan Gris comunicándoselo y citándole para leérselo.

Pasó algún tiempo. Durante el mismo se estrecharon nuestras relaciones epistolares. Su reacción ante algún poema que le envié a su solicitud fue tan sumamente favorable que, si me dejó estupefacto por lo inesperado, creo que contribuyó seriamente a fortalecer mi confianza ante la vida y a hacer posible el desenvolvimiento que ésta adoptó desde entonces. Alguna vez confesé por carta a un chileno, Eduardo Anguita, en un párrafo que éste reprodujo en un artículo de Cuadernos Americanos, que yo no podía imaginarme cuál hubiera podido ser el desarrollo de mi existencia de no haber conocido a Vicente Huidobro. Porque, en efecto, Vicente fue para mí, inicialmente a causa de los poemas a que me he referido y después a causa de nuestra confiada amistad, como una llave que hizo posible la apertura de la multitud de puertas que desde niño habían acumulado sobre mí sus cerrazones. Que aquellos tiempos no eran como los subsiguientes y mucho menos como los actuales.

Consecuencia de esta vinculación amistosa fue que Vicente me invitara en el verano de 1923 a pasar unos días con él y su familia -Manolita, su mujer, y sus cuatro hijos- en una casita que había alquilado en Chatelaillon-sur-Mer, cabe el Atlántico. En una de aquellas tardes en que ahondamos nuestras conversaciones anteriores, los diarios anunciaron en grandes titulares que el general Primo de Rivera había asumido el poder en Madrid. A continuación, Vicente me indujo a acompañarle a París, me hospedó en su casa de la calle de Victor Massé y me llevó a conocer a Juan Gris, a Jacques Lipchitz, a Maurice Raynal, a Waldemar George, los dos primeros de los cuales se convertirían con el tiempo en auténticos amigos míos. 
Relato estos pormenores y los que voy a referir de inmediato como sucedidos de una crónica que, por insignificante que parezca -así me lo parecía a mí entonces-, no deja de poseer alguna relación con el tema del presente Simposio sobre Vicente Huidobro y el vanguardismo.

Porque al poco de regresar a Madrid me topé en la calle de Alcalá con un joven pintor, Bores, que había conocido en la conferencia de Huidobro. Se dirigía con un amigo a un café situado en aquella misma cuadra donde iban a reunirse con algunos ultraístas, Pedro Garfias, Humberto Rivas, Marjan Paszkiewicz y otros que no recuerdo. Me insistieron para que los acompañase, y encandilado como estaba por mi reciente trato con Huidobro, me dejé tentar. Pronto me vi envuelto en una discusión bastante encendida, en la que tuve que hacer frente a todos los contertulios, de los que excluyo a Bores, mero espectador. Entre los poetas, sólo Pedro Garfias pareció dispuesto en algún momento a entender las razones de creación poética que yo esgrimía. Todos estaban afiliados a la negación de las proposiciones de Huidobro, que eran también las mías. Entre otras cosas me dijeron que Guillermo de Torre estaba escribiendo un libro donde trataba de estos asuntos, se le denunciaba a Huidobro y se le ponía en su lugar. Me lo confirmó el propio Guillermo, a quien encontramos en la calle al salir del café, quien se manifestó ante mí con exceso de suficiencia y acritud.

No obstante sus incitaciones, no volví a verlos. Mas en la primera carta que le escribí a Vicente le referí lo ocurrido, a lo que me contestó con fecha 15 de enero de 1924:

Muchas gracias por todo lo que me dice en su carta, por el afecto y el apoyo total que ella me trae. Sería lamentable que esa gentuza tuviese la suficiente fuerza para descorazonarlo y hacerlo volver a su soledad [...]. Escribi sin nombrarle a Ud. al pobre Guillermo de Torre diciéndole que puede decir sobre mí lo que quiera como opinión literaria, que ello no me inquieta, pero que si en su libro hay mentiras y tergiversaciones hipócritas de la verdad de los hechos, voy a Madrid, le doy una vuelta de bofetadas y regreso a París.

Es un pobre niño demasiado arribista para lo tonto que es, y cree que el fracaso de su libro [Hélices] se debe a influencias mías.

¡Figúrese Ud.!

Este incidente nos muestra al poeta tal como era y en su propia salsa de peleador nato en cualquier nivel de la existencia, puesto que en todos ellos se sentía sobrado de energías e impetuosidades que le exponían a fastidiosos contratiempos y desestimaciones. Todo ello militaba contra él en la opinión que de su obra poética se formaban las gentes poco inclinadas a aceptar la validez de sus premisas. Sintiéndose 
superior, distaba de poseer aquella discreción que indujera a perdonarle su preeminencia, así fuese relativa, sobre los demás. Cualidades sobresalientes no le faltaban, ya que la imaginación puesta por él en libertad desde el primer momento y alimentada después con fuertes dosis de entusiasmo y hasta de sacrificio había alcanzado un desarrollo a todas luces infrecuente. Mas tampoco carecía de defectos, ostensibles en ocasiones, y de naturaleza tal que los literatos del contorno se creían autorizados a proyectar la pobre calidad de sus defectos sobre su obra poética y a negarle a ésta la estimación que merecía. Lo cual es lamentable en el campo literario estricto.

Por esta razón, creo que antes de empezar a considerar las cualidades positivas que distinguen a un poeta de la importancia que se atribuía - y tiene- Vicente Huidobro, es indispensable denunciar previamente sus defectos, como quien separa la cáscara de la pulpa de un fruto.

Sí. Vicente Huidobro tenía defectos y pequeñeces humanas, fomentadas originalmente por su vocación al heroísmo. Desde muy joven se sintió impulsado a hacerse presente en el escenario de la época investido con el atuendo voluntarioso de poeta y héroe conforme a las posibilidades que su época de ruptura le permitía. Es muy posible que hubiera leído ya a Carlyle. Lo seguro, de todos modos, es que había asimilado las Dilucidaciones prologales de El canto errante, convocando «a los nuevos poetas de las Españas» a practicar la poesía en su nivel más sublime, inducidos por "la invencible voluntad de crear». Esta exhortación, escuchada por las propensiones de su personalidad, positivamente ambiciosa, le movió a atribuirse la primacía en todo. Tenía que ser el iniciador, el primero, declarándose en aquella situación de tránsito en rebeldía frente al mundo en que había nacido y a sus estribaciones. Todo lo subordinó a este propósito, que fue mostrando serle intrínseco. Aprovechó los favores de su suerte para desprenderse en un acto de generosidad poética de los beneficios económicos y de prestigio que le procuraba su nacimiento. Quemó las etapas. Renunció a la nobleza de su apellido cercenándose el "García». Se casó muy joven y se largó a París con gesto temerario después de haberse convencido en su tierra, merced a la lectura de Emerson, de que la época estaba reclamando su Poeta. Se trataba, pues, de ser ese Poeta, de intervenir en su creación a toda costa; en suma, de crearlo. Angel rebelde, apuntó su imaginación, con ayuda de la ciencia, al cosmos planetario, manifestándose como un nuevo Adán que se atribuye en el orden del lenguaje las eficiencias del Creador domiciliado en los cielos. Se sirve de las palabras como de objetos manipulables, según lo revela prácticamente al compo- 
ner sus caligramas publicados en 1913, con anterioridad a que Apollinaire diese a conocer los suyos. No hay duda de que está en la onda de la época. Y de ahí su afán creacionista que, en una explosión de megalomanía, se propone al mundo entero como YO, como el sujeto genérico en primera persona. Su libro Pasando y pasando comienza con un texto titulado en página blanca "YO». $\mathrm{Y}$ en su página 24 dice que la primera composición en verso que escribió en su vida se titulada «Eso soy yo». Por ese camino, nada más lógico que en Vientos contrarios afirmase: «La poesía soy yo».

Sobre tales fundamentos no cabe extrañarse que a lo largo de su vida adoptase la actitud típicamente satánica del "Quién como yo», y que en el poema «Adán» cante las excelencias de Caín, que, según el mito genesíaco, es cabeza de la rama científica y metalúrgica, y menosprecie el «misticismo de Abel». En semejantes circunstancias, ¿cómo podía no ser normal que, cuando llegase el caso, recurriera al engaño, sobre todo en este mundo donde la mentira se conduce como reina y señora?

Dicen los parapsicólogos no ser infrecuente que los individuos dotados en verdad de dones mediúmnicos acudan en ocasiones al fraude. Lo hacen para convencer a algunos por medios engañosos de que son lo que realmente son, mas en circunstancias en que no se sienten asistidos por sus poderes excepcionales. Lo cual dista de probar, 1) que carezcan de tales aptitudes; y 2) que practiquen sistemáticamente la superchería. Parecidamente, el hecho de que Huidobro acudiese a veces a la ocultación e inclusive al fraude, antidatando, por ejemplo, sus escritos, dista de probar que la sustancia de éstos no fuese genuina y que él no fuese auténticamente el primero. Pudiera sostenerse que ello era más bien prueba a favor de lo contrario. Que si acudió a veces neciamente a tales recursos, fue debido a su calidad intrínseca de precursor, obligado por naturaleza a patentizar que en las huestes de la poesía contemporánea él ocupaba la posición de adelantado.

Yo lo creo firmemente así. Y para ilustrar al vivo esa realidad voy a llamar la atención sobre ciertos episodios literarios que no han sido bien utilizados hasta ahora.

Suele ser costumbre publicar en primer término, cuando se trata de los antecedentes creacionistas de Huidobro, la conferencia Non serviam, donde proclamó en Santiago su independencia de la Madre Natura.

E1 poeta dice a sus hermanos: Hasta ahora no hemos hecho otra cosa que imitar al mundo en sus aspectos, no hemos creado nada.

Hemos cantado a la Naturaleza [...]. Nunca hemos creado reali- 
dades propias como ella lo hace o lo hizo en tiempos pasados, cuando era joven y llena de impulsos creadores...

No hemos pensado que nosotros también podemos crear realidades en un mundo nuestro, en un mundo que espera su fauna y su flora propias. Fauna y flora que sólo el poeta puede crear por ese don especial que le dio la misma Madre Naturaleza a él y sólo a él.

Non serviam. No he de ser tu esclavo, Madre Natura; seré tu amo.

Una nueva era comienza.

Pues bien: ese mismo año 1914 editó Vicente su libro Pasando y pasando, uno de cuyos capítulos finales, titulado «El futurismo», lo dedica a la crítica despreciadora de Marinetti. Y empieza en él por decir que, antes que el poeta italiano, un «admirable poeta y sagaz pensador» de Mallorca, Gabriel Alomar, había proclamado el futurismo. "Y antes que Alomar lo proclamó un americano, Armando Vasseur, cuyo auguralismo no es otra cosa en el fondo que la teoría futurista»... «Por tanto, el futurismo es americano». Con lo cual todo lector queda admirado, sobre todo si no recuerda que de Gabriel Alomar y de su futurismo había hecho mención elogiosa Rubén Dario en sus Dilucidaciones de El canto errante.

Mas lo que Huidobro elude decir es que su Non serviam y su apelación a la facultad creadora del poeta provenía en línea recta del texto de Alomar. Que este último aludió en su conferencia Futurismo de 1904 al primer hombre Adán, diciendo que fue «el primer indómito, el primer protervo, que ha lanzado el non serviam representando la protesta de la humanidad». Y continúa Alomar: "Aquí está precisamente la explicación del fin principal del hombre en su trabajo perdurable sobre la tierra». Modelarla a su arbitrio, «esculpir en el mundo nuestra imagen, crear en fin, crear alcanzando de un vuelo la función misma de la divinidad".

Es obvio que de esta conferencia de Alomar ha tomado Huidobro los conceptos fundamentales de la suya, su Adán, su non serviam y su tendencia intrínseca a crear, "alcanzando de un vuelo la función misma de la divinidad», o sea, de su postulado de que «el poeta es un pequeño Dios». Pero evita confesarlo, posiblemente por el deseo de derivar la gloria de la proposición hacia América (Emerson, Vasseur, Whitman, quizá Darío, silenciado, y él mismo). «El futurismo es americano», sentencia. En contraste con Marinetti, asienta Huidobro, demostrando que ha leído y asimilado el texto de Alomar, que éste «centró más bien la idea de futurista en la personalización, en la individualidad que no teme manifestarse tal como es, en una palabra: en el yo inconfundible», cosa 
esta última que a él le sentaba perfectamente. «Alomar adivina el futurista en el hombre que siente un gran impulso de más allá, de suprasensible, de ultraespiritual, que le insufla chispazos de vida nueva. 'La esperanza de una humanidad mejor'».

Otro de los aspectos notables del caso es que en esas palabras de Huidobro referentes a Alomar está con su más allá, su suprasensible y su ultraespiritual algo más que implícito el germen del ultraísmo, pronunciado por Alomar quince años antes de la aparición del movimiento español de Cansinos-Asséns y de Guillermo de Torre, y en lo que respecta a Huidobro, con diez años de anticipación.

No menos admirable es que el mismo Alomar se encargara de explicitarlo. En el número de marzo de 1919 de la revista Cervantes se imprimió tras un artículo de Pedro Garfias titulado "Anales literarios. El 'ULTRA'», el siguiente pie de página: «El maestro Gabriel Alomar, en carta dirigida al poeta Xavier Bóveda, dice: 'Su lema ultra, ¿no es también el de mi Futurismo, nombre que después me tomó para muy diversos fines Marinetti? Todos vamos hacia la misma estrella epifánica. ¡Excelsior!».

Mas lo expuesto no es todo. Puestos a investigar hay algo que reclama averiguación incisiva. Huidobro sostiene que pronunció la conferencia Non serviam en el Ateneo de Santiago en 1914. ¿Existe de ello alguna prueba? Parece que no. Se carece de evidencias documentales que impongan la certidumbre. Ningún diario ni revista, ningún compañero juvenil ni estudio de investigación se ha referido nunca, que sepamos, a semejante conferencia pública. El mismo Vicente no la mencionó en sus alegatos hasta 1925, en que la publicó con una escueta mención a la cabeza de sus Manifestes. Por tanto, y teniendo en cuenta las debilidades de Vicente en este orden de cuestiones, la crítica se ve obligada a preguntarse si dicha conferencia de 1914 tuvo lugar realmente o si no fue más bien una invención muy posterior del poeta, justificado quizá por la idea de que, por haber tenido ya conocimiento de Alomar en 1914, pudiera haberla pronunciado. Duele tener que aceptar como más probable que nos encontremos ante un episodio fabricado a favor de la primacía que en sus polémicas se arrogaba Vicente respecto a la génesis del creacionismo. Pero dejemos bien expreso que ello en nada afectaría a la calidad poética de la obra de Huidohro, tan superior por entonces, en cuanto a potencia creadora, sobre los otros poetas coetáneos. Se limitaría a desenmascarar los excesos de su creatividad incontenible.

Tomaremos otro ejemplo importante. En su otra muy mencionada cnnferencia, dictada ésta en julio de 1916 en Buenos Aires, donde tanto insistió, según relataba, sobre la función del creacionismo y su «Arte 
poética», decía: «¿Por qué cantáis la rosa? ¡Oh poetas! / Hacedla florecer en el poema». Y añadía sobre ello años después, sosteniendo que «toda la historia del arte no es sino historia de la evolución del Hombre-Espejo hacia el Hombre-Dios:

Esta idea del artista como creador absoluto, del Artista-Dios, me la sugirió un viejo poeta indígena de Sudamérica (aimará) que dijo: «El poeta es un Dios; no cantes a la lluvia, poeta, haz llover» ( $L a$ création pure, 1931).

Al exigente que no se contenta con meras afirmaciones ha de interesarle saber quién es ese poeta aimará, presumiblemente boliviano, cuya identidad nunca se decidió a revelar Vicente a sus lectores. Todo ello quedaría en el secreto del sumario de no venir a llamarnos la atención de pronto un dato bastante sugestivo en este aspecto, que nos obliga a referimos otra vez a Maurice Raynal y a su libro Peinture Moderne. En el capítulo "Avant le cubisme», con referencia especial a los años 1906 y 1908, afirma que la estética cubista estaría dominada por el papel preponderante que atribuye a la creación. Y dice, ocupándose particularmente de poetas pintores:

Los artistas han visto abiertos sus horizontes a través de este verso de un antiguto poeta hindú: «Oh, poète, ne nous parle de la pluie, fait pleuvoir plutôt».

En este testimonio se atribuye a un antiguo poeta hindú aquello que en la pluma de Huidobro se atribuye a un viejo poeta indígena de Sudamérica (aimará). El objeto de que se trata es idéntico. Tan idéntico que surge espontáneamente la pregunta: ¿quién lo tomaría de quién? En la ardiente polémica sobre prioridades sostenida por Huidobro frente a Reverdy y compañía, ¿caería ante los ojos del chileno la frase que más tarde transcribirá Raynal, y la adaptaría a las conveniencias de su argumentación a favor de Sudamérica? ¿O más tarde Raynal oyó en el medio en que se desenvolvía denunciar la identidad del concepto y se complugo en dejarlo registrado en descrédito del prepotente poeta sudamericano amigo suyo, que lo utilizaba con fines distintos? Desde luego esto último explicaría el extraño porqué suprimió Raynal el nombre de Huidobro en lo relativo a la creación de Nord-Sud.

En la misma línea se inscribe el tan debatido asunto de las ediciones de El espejo de agua, que para muchos es cosa resuelta a favor de las alegaciones de su autor. Por mi parte, aunque mire con gran simpatía tal convencimiento, no me estimo todavía tan seguro como para pro- 
nunciarme rotundamente, porque a mi juicio existen aún en la cuestión diversos puntos oscuros que piden esclarecerse. El hecho de que se haya mostrado un ejemplar de la cuestionada edición de Buenos Aires por conducto de Braulio Arenas, aunque muy digno de tomarse en consideración, no es quizá enteramente probatorio por sí mismo. Como es sabido, el amigo más cercano de Huidobro en Francia era Juan Gris, quien fue además su maestro en materias artísticas. Pues bien: Gris estaba convencido de que la primera edición había sido una artimaña debida a la imaginación traviesa de Vicente. Cierto es que, cuando así se expresaba, la posición de Gris relativa al poeta había cambiado por completo a causa de motivos que luego se expondrán. Pero su versión de El espejo de agua, oída por mí de sus labios, era la siguiente: A la vez que editaba sus cuatro libros nuevos durante su estancia en Madrid, estimó Huidobro conveniente publicar El espejo de agua. Pero, según Gris, había hecho imprimir a la vez, no sabía si en la misma casa, dos ejemplares de una supuesta primera edición fechada en Buenos Aires dos años atrás. Por consiguiente, la aparición de un ejemplar de 1916 en manos de Braulio Arenas, que era entonces la persona que, como dedicada a preparar la edición de las Obras completas, estaba en relación estrecha con los herederos de Vicente, no es por sí probatoria dada la versión de Gris. Sería preciso cotejarla cuidadosamente con la edición de 1918, que curiosamente carece de pie de imprenta, mientras los otros dos libros en castellano salieron de los talleres de Pueyo. Tampoco nadie ha sabido nada hasta ahora de ese «Fernán Félix de Amador, poeta hermano», a quien aparecen dedicadas ambas ediciones y a cuyo testimonio no recurrió Huidobro cuando se puso en duda la autenticidad de la edición bonaerense. De otra parte, nadie en Chile, ni siquiera las Antologías poéticas que se imprimieron poco después, menciona dicho libro, no obstante que en alguna se registran los madrileños de 1918, etc. (Notemos que las tipografías de Poemas árticos y de El espejo de agua son distintas). En fin, es preciso sortear muchos motivos de perplejidad para aceptar de plano la versión de Huidobro. Pero evito pronunciarme sobre la cuestión hasta contar con elementos de juicio probatorios. Lo que no quita para que en el momento actual mi impresión sea que las probabilidades pesan más en disfavor que en favor de la tesis de.Vicente.

Dejo para después la cuestión que provocó la ruptura entre Gris y Huidobro a fin de tocar previamente el asunto del creacionismo. Es seguro que, viniérele la idea de donde le viniere, de Rubén Darío, de Alomar o de Vasseur, para quien lo importante era, según Huidobro, «el acto de creación» - expresión de Alomar-, por temperamento 
estaba Vicente convencido antes de llegar a Europa de que la época aquella que esperaba a su Poeta exigía de éste el desarrollo de sus facultades creadoras. Cuando entró en relación con los medios artísticos de París, se encontró con que el ambiente y las personas que practicaban el ejercicio poético participaban de ideas y sentimientos afines a los suyos. Dice él mismo:

En la época de la revista Nord-Sud, de la que fui uno de los fundadores, todos teníamos más o menos la misma orientación en nuestras búsquedas, pero en el fondo estábamos bastante lejos unos de otros.

En efecto, las líricas de Reverdy y de Huidobro se distanciaron al poco, sin guardar mucha relación entre sí. De aquí que la creencia de que Huidobro imitaba a Reverdy, según afirmaba éste, si se les cree a Gómez Carrillo y a Guillermo de Torre, tenga visos de aberración. El lirismo de Vicente, dotado de matices épicos, correspondía al horizonte donde reina la imaginación creadora con sus esplendores metafóricos, mientras que los de Reverdy, Dermée y colindantes eran más apegados a la superficie de las emociones de lo indeterminado y misterioso. Pero ello no impedía que en 1917 estuvieran arrastrados por una tendencia similar a la creación. Ya se vio la opinión de Raynal respecto al campo de donde brotó el cubismo. He aquí cómo se expresaba Reverdy en marzo de ese mismo año:

Nos hallamos en una época de creación artística $[\ldots]$ donde se crean obras que, desprendiéndose de la vida, a ella vuelven porque poseen existencia propia.

El mismo Apollinaire participaba de convencimientos semejantes, hasta sostener, ya en 1913, que el artista «debe darse ante todo el espectáculo de su propia divinidad». Existe además un testimonio bastante notable, ignorado sin duda por Huidobro, mas no por ello menos impresionante en cuanto al sentido de la época. Proviene de un artista francés de antecedentes sudamericanos, puesto que la abuela de quien lo pronunció era nada menos que la peruana Flora Tristán. Vale la pena registrar los términos en que Paul Gauguin se dirige a sus compañeros en su libro Avant et après publicado en 1903, sin perder de vista las afirmaciones huidobrianas:

No trabajéis tanto según la naturaleza. El arte es abstracción. Tomad de la naturaleza lo que de ella veáis en vuestros sueños... ¿Por qué no podríamos llegar a crear armonías diversas que correspondan a nuestro estado anímico? 
Según se dice, Dios tomó en sus manos un poco de arcilla e hizo todo lo que sabéis. Si el artista, a su vez, quiere sacar a luz una obra creadora, no puede imitar a la naturaleza, sino que debe tomar los elementos de la naturaleza y crear un elemento nuevo.

El error de Vicente al caer en ese medio artístico francés tan en sintonía con sus convencimientos y propensiones pudo ser imaginarse que su entusiasmo juvenil, la agilidad y carencia de obstáculos de su imaginación le permitirían convertirse en personalidad que agrupase en torno suyo a la vanguardia no sólo francesa, sino europea. A ello obedecían sus giras por España, Alemania, Suecia y sus conferencias en París.

En el capítulo de su experiencia parisina de la época se inscribe el episodio ciertamente confuso de su rapto, que contribuyó en gran medida a forjar su descrédito. Había publicado hacía algunos meses un librito de propaganda política titulado Finis Britannia, cuando el 11 de marzo de 1924, en vez de regresar a su casa, recibió Manolita, su mujer, una esquela recomendándole que no esperase a su marido porque lo habían encerrado «bajo siete llaves». Alarmadísima, Manolita acudió a la Policía y a la representación diplomática de su país. Juan Gris y su mujer, Josette, se personaron como amigos de la familia en casa de los Huidobro para acompañarlos y hacer frente a la avalancha de reporteros y conocidos. No existía pista alguna, mas la Policía no tardó mucho en sonreír cortésmente. $Y$ he aquí que a los tres días reapareció Vicente medio atontado y con un pijama bajo el brazo. Su versión del suceso tal como él mismo se la relató a Juan Gris y se publicó en Paris-Journal fue la siguiente:

Por romanticismo político y como miembro de una sociedad secreta irlandesa había escrito y publicado su librito. A fin de castigarlo y obligarlo a desdecirse, otra sociedad antagonista, ésta británica, lo atrajo mediante un ardid a la Porte d'Auteil, donde fue metido en un automóvil y cloroformizado. Se despertó en una casa desconocida. Durante tres días le conminaron allí con diversas amenazas para que firmase una declaración retractándose, a lo que repetidamente se negó con la mayor energía. Mas en virtud del revuelo armado por la prensa, agregado como era Vicente al cuerpo diplomático, volvieron a drogarle y lo depositaron en la rue de Vintimille, a sólo cuatro manzanas de su casa. Lo malo para el poeta fue que las investigaciones llevadas a cabo por la Policía la indujeron a recomendar a la Legación y a la familia que desistieran en sus averiguaciones porque el episodio era novelístico. El resultado fue que Gris, constituido esos días en la casa, acabó por creer en la versión 
de los polizontes y le pidió a Vicente que, para sostener sus dichos hasta sus últimas consecuencias, necesitaba que el reaparecido le diese pruebas de su amistad revelándole la verdad exacta de lo ocurrido, ya que en caso contrario no podría seguir considerándolo amigo suyo. Todo ello lo supe pormenorizadamente dos años después de labios de Gris. Pero incapaz de desdecirse, Vicente continuó aferrado a su versión.

Consecuencia de ello fue que Gris no volviera a verlo más y que por el conducto del amigo y marchante del pintor, Henry Kahnweiler, cundiese por los medios artísticos de la Ciudad Luz la convicción de que Vicente era un farsante. $\mathrm{Y}$ a grado tal de severidad llegó el rechazo de Gris, que estando éste ya muy enfermo, Vicente, que se hallaba de nuevo en París, pretendió verle. Me encargó que le transmitiese a Gris su deseo de visitarlo. Pero Gris se negó a recibirlo. «-Mejor no», me respondió. «-Dígale que mejor no». Lo que seguramente constituyó una de las experiencias amargas que con el transcurso de los años contribuyeron a madurar el diamante que se encerraba en el pecho de Vicente hasta manifestarse en su desnudez en los poemas finales.

Mas a propósito de estas penosas aventuras, parece imaginativamente adecuado, puesto que se trata de un poeta, advertir la conexión literaria que existe entre estos episodios irlandeses de 1924 y el largo poema que no sé si escribió, mas sí publicó en 1932, «Temblor de cielo». En él se declara con grandiosa elocuencia y en términos abismales la entrega total del poeta a la personificación de la Poesía bajo el extraño nombre de Isolda, princesa de Irlanda, donde se augura otra vez el fin del universo y su fin propio. Esta es cosa que, por otra parte, le confiere reflejamente al sujeto poético y a sus aventuras la fisonomía heroica de Tristán, el héroe batallador de la saga británica.

Con esto puede darse por terminado, provisionalmente al menos, el examen del reverso o aspecto negativo de la medalla de Vicente Huidobro. Para efectuar el tránsito al anverso o apreciación positiva, se cuenta con el extraordinario poema Altazor, que algo participa de ambas imágenes. Se sabe que salió de la imprenta en 1931. Pero como carece de colofón y de pie de imprenta fechado, para quienes lo leyeron ingenuamente durante bastante tiempo era éste un poema publicado, o al menos compuesto, en 1919, por ser la fecha que figura en la anteportada. Así, en la Antología compuesta por Eduardo Anguita y supervisada por Huidobro se lee en la página bibliográfica: «Altazor, poema (1919). Edit. C.I.A.P., Madrid, $1931 »$.

Sobre este problema aduje algún elemento de juicio en respuesta epistolar al profesor David Bary hace años, citada por él en su estudio «Huidobro o la vocación poética». Por lo pronto, parece incuestionable 
que Altazor empezó a redactarse en el invierno de 1919, a los seis meses de la aparición de Ecuatorial, puesto que así se declara en su Canto I. De otra parte, recuerdo un dato que no figura en sus bibliografías. Guardo muy presente haber leído un trozo de Altazur en un diario de Madrid, no sé si El Imparcial, La Correspondencia de España o en algún otro de sus contemporáneos. Debió aparecer o a fines de 1921 o a principios del 22, ya que no lograron dar con él quienes lo han buscado por encargo mío en fechas más tempranas. Con anterioridad a 1928, Huidobro no nombraba más a Altazur en sus conversaciones, que yo recuerde, ni aun cuando me entregó para Favorables un texto que resultó luego ser parte del Canto IV; sí, en cambio, a Cagliostro, Gilles de Raiz y con frecuencia a $A u$ revoir. Sólo en 1928-29, si no recuerdo mal, volví a oírle referirse a este poema que parecía estar trabajando, y me advirtió que ya no se llamaba Altazur, sino Altazor. No deja de intrigar al respecto que los varios fragmentos de este libro publicados en 1926, «Poema» en Panorama, "Venus» en Favorables, unos versos en Hangar, de Lima, pertenecieran todos al Canto IV, lo mismo que el trozo en francés dado a conocer más tarde en Transition. Ello invita a sospechar que hacia 1926 Vicente estaba revisando o retocando al menos su gran poema. Sin embargo, no debió ser ese año cuando se produjo el tratamiento final, puesto que en ese mismo Canto IV es donde se define el nombre del héroe: "Aquí yace Altazor azor fulminado por la altura / Aquí yace Vicente antipoeta y mago", mientras que en Vientos contrarios, precisamente de ese mismo año, se anunciaba como próximo a publicarse Altazur, nombre que, según advirtió David Bary, se repite en el interior del texto. $Y$ aún se complica el asunto al leer en Vientos contrarios que el Canto $\mathrm{V}$ lo compuso en el cuarto que ocupó Nietzsche en Silvana Plana. Quizá no es forzoso entenderlo al pie de la letra, puesto que lo mismo pudiera ser un trozo del Canto IV. De otra parte, no se sabe en qué momento pudo detenerse Huidobro en ese lugar de Suiza. En lo que respecta al nombre inicial del personaje, no cabe desconocer que, en la parte primera de La gruta del silencio, Vicente utilizó como lema el verso mallarmeano: "Je suis hanté. L'Azur! l'Azur! 1'Azur! l'Azur!», cuya obsesiva resonancia bien pudo sugerirle a su hora el nombre Altazur de su alter ego cósmico.

De lo examinado se desprende que el gran poema Altazor participa de la inclinación del poeta a no respetar la inviolabilidad del tiempo objetivo, sino de modificarlo a su arbitrio. Es ésta una debilidad en perfecta sintonía con el temperamento de quien anhelaba convertirse en el creador intemporal del universo humano. «Soy todo el hombre» (Canto I). 
Altazor debió iniciarse en 1919, como reza la portada, y es probable que el Prefacio y los Cantos I y II se compusieran en esa fecha, aunque se ignora si fueron o no retocados o reelaborados con posterioridad. En el Canto II, dedicado a la Mujer, se repiten versos escritos para Manolita, su esposa, en Las pagodas ocultas, de 1914.

Aunque carezca de datos concretos para fundar un convencimiento firme, parece muy dudoso que el poema se concibiera desde un principio sobre una estructura de siete cuerpos ascendentes, dado que su sentido inicial fue el de la Caída: en primer lugar, hacia el sepulcro (Prefacio), y de otro, la caída cósmica, equiparable a la mitológica del ángel caído, a la manera de Lucifer (Canto I).

No faltan indicios para presumir que esa estructura septiforme no fue concebida originalmente, sino que fue resultado de circunstancias debidas al paso del tiempo, e inclusive al de las modas literarias. Los juegos lingüísticos del Canto IV, correspondientes algunos al estilo periodístico propio del «instante prosaico», según dice en ese mismo Canto, y también el modo como atenta en otros juegos contra la constitución morfológica de las palabras, libertades que reinarán en adelante hasta el final, sólo se tornan comprensibles cuando varios años más tarde del presunto 1919 ganaron boga entre las vanguardias francesas los poemas despojados de todo acento poético y se divulgaron las audacias linguíisticas de Joyce. El mismo afán de figurar en primera línea pudo inducirle a Huidobro a componer los textos de esa naturaleza, sin parentesco ni lejano con su Tout à coup de 1924, mucho menos con los estilos practicados por él con anterioridad. Mi impresión personal, pues que se carece de datos fidedignos para sentar juicio más consistente, es que los Cantos posteriores al III traducen la transformación psicológica experimentada por el poeta en 1926, cuando escribió Pasión y muerte, y penetró en otro círculo expresivo menos riguroso. Muy de tener en cuenta es la diferencia de volumen que presentan los Cantos entre sí. $Y$ el hecho de que se publicaran varios trozos del Canto IV en 1926 libres de todo apresto poético contribuye a sustentar esta suposición. Los VI y VII, aunque coherentes dentro de la formalización septenaria del conjunto, no se justifican relativamente al volumen que traía la marea poética y más parecen aditamentos artificiosos para justificar y redondear numéricamente a la totalidad que, quizá casi espontáneamente, se había venido perfilando. Las numerosísimas repeticiones del Molino, mero relleno para sugerir quizá la monotonía del eterno retorno, son o demasiado pocas, puesto que los diccionarios de la rima registran unas dos mil voces terminadas en ento, o simplemente demasiadas para el aguante del lector. 
De desear sería que las anteriores hipótesis pudieran confrontarse algún día con otros documentos, y en especial con los borradores y primeras versiones del poeta. Mas, de todos modos, del texto de Altazor parece desprenderse en primer lugar que este poema no fue producto de un esquema preestablecido. Y después, que la segunda mitad del poema pudiera ser varios años posterior al impreso en su portada. Esto induce a situarlo en el grupo de las obras que se pliegan a la tendencia huidobriana de disfrazar en ocasiones las fechas de sus escritos para aparecer sin necesidad aparente como precursor, cosa que en virtud del carácter de su persona se presta a interpretarse como realmente significativa.

Tras lo dicho ha de examinarse ahora en perspectiva panorámica la forma del poema en su figura integral. Independientemente del modo como fue compuesto y de sus debatibles estructuras, Altazor resulta ser, escudriñado a fondo, un fenómeno cultural de muy alta jerarquía; un monumento metafórico de realidades extrahumanas que constituye algo así como la clave de bóveda de la experiencia ambiciosísima de su autor e inclusive - contra él mismo- de nuestra cultura.

Altazor, su héroe total, al modo de Zaratustra, aunque en otra esfera, es por lo pronto un personaje deliberadamente representativo según el nombre que se le inventa, Altazur inicialmente, más tarde Altazor, con resonancias el primero, según sugerimos, de un verso de Mallarmé. Como la fisonomía de las personas suele manifestarse desde muy temprano, no nos extrañará que la figura del héroe sea ya reconocible en una de las primeras composiciones de Huidobro, «La epopeya de Iquique», de su primer libro Ecos del alma. Se le oye en él al poeta dirigirse así, como augurando su propio destino literario, al héroe Arturo Prat:

Noble águila marina, volabas insegura, Midiendo del espacio la eterna inmensidad, La pequeñez de abajo mirando de esa altura Te hizo volar al cielo de la inmortalidad.

Desde la primera frase del Prefacio, Altazor se identifica simbólicamente, sugiriendo su conexión con el Zaratustra anticristiano de Nietzsche. «Nací a los treinta y tres años, el día de la muerte de Cristo». Altazor es además el nombre heroico de Vicente Huidobro según lo reconoce en el Canto I. "Soy yo, Altazor, el gran poeta». "Justicia, ¿qué has hecho de mí, Vicente Huidobro?». Más adelante insistirá varias veces en proclamar ésta su misma identidad. «Soy yo Altazor, el doble de mí mismo». "Aquí yace Altazor»... «Aquí yace Vicente» (Canto IV). 
Conforme a los conceptos junguianos, a propósito precisamente de Nietzsche, cuya disponibilidad mental producida por su ateísmo se vio poseída por las personalidades de Zaratustra o Dionisos, puede decirse que en la hipertrofia yoísta de Huidobro se alejó con entereza demoníaca el «complejo autónomo» de Altazor. Ello en el nivel metafísico y acosador del absoluto que, desprendido de la corteza terrestre, se pasea y pasea sus vértigos angustiados en el espacio cósmico. Que en el plano terrestre aquella su misma disponibilidad ególatra se invistió en la volición del poeta, como es sabido, con las magnitudes de Napoleón, de Don Juan, del Cid Campeador, y en lo poético reflejamente del héroe Tristán de Lionés, el amador de la bella Isolda.

Al decir Altazor-Huidobro que nació el día de la muerte de Cristo, parece estar suplantándole a éste en cuanto personaje definido por la ascensión a esos cielos por los que Vicente pasea sus lirismos desmesurados, cósmicos. De aquí que una exégesis sin inhibiciones pudiera tal vez atreverse a sugerir que, sin pretenderlo, el Altazor que cae en su paracaídas está representando por inversión dialéctica aquel trance que en la tradición de nuestra cultura ha sido designado con el nombre de Parousía, Segunda Venida, o simplemente Advenimiento del Señor, que ponga fin a la llamada era cristiana. Dice: «Abrí los ojos en el siglo / en que moría el cristianismo» (Canto I). Es de advertir que, lanzado desde su mocedad al campo de lucha contra las creencias de sus mayores, Huidobro carecía de instrumentos culturales y de sensibilidad para distinguir entre cristianismo y catolicismo romano. Cuando afirmaba en Ecuatorial: "Ayer vi muerta entre las rosas / la amatista de Roma», daba por segura la muerte del cristianismo, cosa que en realidad dista de ser $\tan$ segura. Lo indudable es que estaba interpretando apocalípticamente los terribles acontecimientos de aquella situación de ruptura en el cuadro ideológico de Nietzsche. "Cuántas veces la vida habrá recomenzado», había escrito junto al Alfa y la Omega en la última página de Ecuatorial conforme a la creencia en el «eterno retorno».

En cuanto a la estructura del poema, dividido en siete Cantos, es obvio que su sucesión configura una escala, instrumento formal que traduce la progresión correspondiente a todos los procesos psíquicos lo mismo de orden individual que colectivo o cultural, diagramados así desde tiempos ancestrales. Sus siete niveles o peldaños coinciden cabalmente con las tradiciones más representativas en esta especie de ideas y figuras.

En la presente ocasión se advierte de entrada que, si toda escalera está concebida como instrumento de paso de un nivel a otro nivel, su presencia aquí parece estar manifestando la voluntad ascensional del 
poeta, que a partir de una situación discursiva, donde exhibe su estado personal de conciencia, sus sentimientos, vértigos y angustias, despliega su voluntad de trepar al punto cúspide del último Canto. Esto en cuanto a Vicente Huidobro. Pero al mismo tiempo, para quien contempla el fenómeno con exigencia enteramente objetiva, tórnase visible que este proceso del poeta parlante está patentizando en cuanto a su doble, $A l$ tazor, las transformaciones experimentadas por la progresiva ascensión del lenguaje. Que éste, el lenguaje, no sólo constituye la sustancia misma del instrumento ascensional a la manera de los caligramas, sino que, en razón de los estados intermedios que acusan distintas formas y alteraciones lingüísticas, termina en estado de disolución, reducido a unos pocos sonidos inarticulados. Todo induce a presumir curiosamente que, como punto final en su ascensión, el lenguaje ha llegado a exhalar su último suspiro.

Ahora bien: puesto que a la vez que traduce el contenido anímico del autor pudiera este notable objeto de literatura enigmática estar por su propia sustancia linguística dispuesto para la comunicación de algo más, inclusive intrínseco, una crítica ambiciosa, como el poema lo es, no puede darse por satisfecha con los significados de superficie perceptibles por los lectores de primeros grados.

Avanzando, pues, hacia significaciones más profundas, la crítica ha de empezar por preguntarse qué es lo que la intuición del autor, por expresarse así, exaltado por sus conflictos internos en el orden de la vivencia psicopoética, procura consciente o tal vez inconscientemente dar a conocer. Con este propósito, y teniendo en cuenta que, aunque redactado en español, no guarda este poema afinidad con nada de lo escrito en nuestro idioma, y que además fue compuesto en Francia por alguien que aspiraba a desempeñar un rol en la poesía de aquella lengua y país, la curiosidad crítica tiene por fuerza que orientarse hacia las condiciones reinantes en aquel conclave internacional.

En esta perspectiva, de inmediato se advierte que la intención formalizada en Altazor presenta rasgos de equivalencia con los propósitos que animaban al príncipe de los poetas franceses y gran maestre del Simbolismo, Stéphan Mallarmé. En sus ensayos, en su correspondencia y en sus conversaciones dejó Mallarmé bien declarado que en el horizonte poético existían dos lenguajes posibles: el discursivo de la poesía convencional, de cuyo nivel se proponía desprenderse por superación, a la vez que su conciencia subjetiva se desprendía de su personalidad propia en procura de un absoluto que acabó identificado con la Nada. Guiado por estos convencimientos y con miras al lenguaje supremo en el que la imaginación lo es todo, Mallarmé compuso su obra maestra, 
Un coup de dés, que por sus extralimitaciones tanta influencia ejerció en los destinos literarios (postsimbolismo, futurismo, joycismo, surrealismo). Sabido es que en su texto se trasunta plásticamente una partitura musical con fulgores de tempestad marítima y de resonancias siderales.

Ante esta confrontación, no de apariencias exteriores, sino de sustancias psíquicas, no cabe duda de que Vicente Huidobro, establecido en los medios poéticos que en Francia reconocían el magisterio de Mallarmé, estaba, cuando componía las estaciones de su gran poema, cultivando los surcos ulteriorizantes roturados por el maestro simbolista.

Mas si se ha de llegar al fondo de la cuestión, es preciso percatarse de que al pensar Mallarmé como pensaba no estaba formulando una innovación plenamente suya, sino que estaba recogiendo y prolongando a sus consecuencias lógicas una intención que traía la poesía occidental desde las ansiedades románticas. En la línea realmente creacionista de Poe y de Baudelaire, y en sintonía con Nerval, esos impulsos dieron ocasión a que Rimbaud, recogiendo la antorcha, se propusiera inventar desde sus Voyelles y Alchimie du Verbe una lengua nueva «del alma para el alma», así como dar un salto en poesía y en vida al más allá anhelado por sus predecesores. Gran admirador de Rimbaud y de su satánica voluntad de rebeldía y desorbitación, nuestro Huidobro estaba predispuesto para concebir y llevar a término un poema como Altazor, que en la prolongación de Mallarmé satisfacía sus instintos creadores, especialmente desde que se dio a conocer la carta de Rimbaud a Démeny en 1928. Sobre que Guillaume Apollinaire, la personalidad más escuchada de la poesía de entonces, hacía suyas las proyecciones sustanciales de la poesía francesa, que extendía a la pintura, llegando a pronunciar propósitos como el que dice en uno de sus poemas últimos, "La Victoire»: «Oh bocas. El hombre está en búsqueda de un nuevo lenguaje. Se desean sonidos nuevos, sonidos nuevos, sonidos nuevos».

Acerca de la realidad de este planteamiento teórico, me es dado aportar con respecto a Vicente Huidobro mi testimonio personal. El concepto de los dos lenguajes y de la intención conscientemente constructiva de Poe-Mallarmé, con proyección a su más allá de la poesía francesa, fue enseñanza que Huidobro me transmitió oralmente a partir de su disertación de 1921 en Madrid, y que quedó en vigencia entre nosotros como un axioma compartido y apadrinado por Juan Gris. En lo que me concierne, ello explica el giro que tomaron desde entonces mis actividades líricas hasta que desembocaron en otro campo poético $\mathrm{y}$, por intervención de los hados, en el entendimiento de lo que estimo ser un logos cultural de otra especie y trascendencia.

Esto dicho, no exige esfuerzo percatarse de que Altazor se desliza 
por los rieles recién esbozados, con la voluntad de alistarse y de prolongar el destino que venía trazándose en las andanzas esenciales de la poesía francesa con miras a la universalidad. Pero el caso es que desde Santiago de Chile y de sus primeros chispazos creacionistas, la intuición de Vicente estaba buscando en teoría un lenguaje poético nuevo y universal para su nuevo "Adán». Así, decía en este poema que «en la garganta del poeta, el universo busca su voz, una voz inmortal». Nada más preciso para revelar la medida de las aspiraciones desmedidas de su Altazor, así como su desesperación por saberse condenado a muerte. Ha de advertirse que, así como la experiencia psíquica de Mallarmé desemboca en la Nada, la que concluye en el Canto VII de Altazor termina en la descomposición de los vocablos, o sea, en el delirio mortal de las Vocales identificadas por Rimbaud.

Ahora bien: si dentro del área entera de la cultura se considera a la poesía como manifestación privilegiada del ser humano en cuanto quintaesencia del lenguaje, capaz por lo mismo de revelar las sustancias ulteriores, cabe sospechar que la aparición de Altazor en nuestro idioma puede desempeñar alguna función significativa - comunicativa- independiente, como lo son los sueños, de la conciencia y de la voluntad de la persona en que se producen. Evidentemente, una revelación de este género no podría ser de orden individual, puesto que el lenguaje, aunque en su primer nivel sirva para la comunicación de los individuos entre sí, no es en lo intrínseco una razón individualista, sino sustancialmente colectiva, apta por consiguiente para revelaciones de muy otros alcances.

En principio, pues, el hecho de que Altazor sea un sujeto-objeto de índole poética induce a considerarlo como un fenómeno verbal en perfecto acuerdo con las intuiciones de su autor, que llegará a decir en su manifiesto Total, escrito, decía, en Madrid y en el mismo año en que apareció Altazor: «En el principio era el Verbo, y al final será el Verbo». Y añade: «el verbo cósmico, el verbo en el cual flotan los mundos [...]. La voz de una civilización naciente, la voz de un mundo de hombres y no de clases». Bien definida está en estas palabras la aspiración impulsiva que había animado al poeta cuando componía Altazor paseándose por los espacios cósmicos. Alfa y Omega otra vez. Apocalipsis. Al fin será el Verbo, la palabra esperada por Lázaro para incorporarse, dirá también. Estamos en el santuario del logos, laboratorio de los grandes mitos.

Procede, de otra parte, tener presente que la forma que le es consustantiva al lenguaje en que Altazor ha plasmado su figura, expresa en el campo cultural, razones en modo alguno despreciables. Desde luego, el 
número siete es número sagrado en nuestra tradición, entrañado a los mitos básicos de nuestra revelación ontológica. Es el número del heptameron o sucesión de siete días en que Dios creó al Universo y lo coronó con la modelación del hombre. De aquí que se reiterara el motivo en diversas circunstancias históricas señaladas. De él proviene el concepto de nuestra semana, extendida por el mundo entero; los siete brazos del candelabro que ardía en el Santísimo; las siete luminarias celestes; los siete Espíritus de Dios (Henoch, Apocalipsis, etc.); los siete pilares de la casa de la Sabiduría; los seis peldaños del trono de Salomón, que, como Adán, se sentaba en ellos como séptimo. Muy especial es en este orden de ideas el modo como los Evangelios de Marcos y Mateo presentan la transfiguración del Señor. Dicen con referencia al nivel témporo-espacial de los mayores mitos: «Después de seis días, Jesús toma a Pedro y a Jacobo y a Juan y los lleva aparte a un monte alto y se transfiguró delante de ellos». El Cuarto Evangelio se encargará de revelar que Jesús es el Verbo, situado así en el día séptimo del nuevo Adán paradisíaco. Ello induciría a imaginar que Altazor, mediante su estructura y sus siete letras, delata al anti-verbo como fruto del anticristianismo de Nietzsche. El hecho de que se puedan emitir tales conceptos con motivo de este poema es ya de por sí un signo de su excepcional trascendencia, sobre todo si se tiene presente que toda nominación negativa da de por sí testimonio indirecto de la positiva en que se sustenta.

Mas no se detiene aquí el asunto. Trasladándonos del campo de los valores confesionales a los desacralizados de las culturas, aunque siempre en el orden religioso, acude de inmediato a la memoria la figura del zigurat o torre característica de los templos caldeos, cuyos siete niveles o peldaños daban lugar a que en el séptimo se celebrase figurativamente la unión del cielo y de la tierra. Representación de estos monumentos instrumentales es la famosa Torre de Babel, identificada asimismo con la realidad del lenguaje, o mejor de los lenguajes cuantitativos y cualitativo o de los hombres y de Dios, en dualidad equivalente a la establecida en las mentes de Mallarmé y de Huidobro.

Corroborativamente se le oye exponer conceptos muy pertinentes a un erudito de autoridad reconocida, Mircea Eliade, en el capítulo de su libro Images et Symboles, donde se ocupa del «simbolismo de la ascensión». Afirma que la escalera de siete peldaños para subir al cielo es un símbolo antiquísimo y generalizado en el campo de las culturas, siendo una de ellas la que al propagarse extendió el culto de Mitra. De esta escalera dice que «figura plásticamente la ruptura del nivel que hace posible el paso de un modo de ser a otro». Comprueba también que se encuentra frecuentemente en la literatura psicoanalítica, y añade, coin- 
cidiendo con Jung: «La escalada o la ascensión simboliza el camino hacia la realidad absoluta». Si se le concede a esta especie un grado suficiente de certeza, habría que admitir: $1 .^{\circ}$, que Altazor representa estructuralmente la figura que podría haber tomado la experiencia de Mallarmé en sus proyecciones subjetivas más ambiciosas, y $2 .^{\circ}$, que, al escribirlo, Huidobro estaba diseñando una parodia mística, según lo sostenido por David Bary, que ilustra su propia proyección mental al absoluto.

Complementariamente, Mircea Eliade sostiene que la figura septenaria se encuentra en relación estrecha con el símbolo cuadrilátero del mandala y con el «centro del mundo». La experiencia de la humanidad demuestra, según Eliade, que el hombre no puede vivir sino en un espacio sagrado, sentido como centro. La constancia de este sentimiento revela una

condición humana en el cosmos que podríamos llamar «la nostalgia del Paraíso». La entendemos como el deseo de encontrarse siempre y sin esfuerzo en el corazón del mundo, de la realidad y de la sacralidad; en suma, de sobrepasar en forma natural la condición humana y recuperar la condición divina - un cristiano diría la condición anterior a la caída (Traité d'histoire des religions).

\section{Y dice también en Images et Symboles:}

Todo ser humano tiende, aun inconscientemente, hacia el Centro y hacia su propio centro que le confiere la realidad integral, la sacralidad. El deseo profundamente arraigado en el hombre de hallarse en el corazón mismo de lo real, en el Centro del Mundo, allí donde se efectúa la comunicación con el Cielo, explica el uso inmoderado del "Centro del Mundo».

Evidentemente, todo este resumen de las compulsiones y apetencias trascendentales de los grupos humanos desde la prehistoria le sienta como traje cortado a medida a Altazor y a su poeta. Que la figura del «Mandala» sentida como centro del mundo se halla patente en lo imaginado por Huidobro al trasladarse e instalarse en el «centro del mundo», que era entonces París, y concebir allí la cuadratura de su Horizon carré, uno de cuyos poemas, «Matin», es encuadrado por la palabra Soleil, escrita cuatro veces en sus cuatro costados o puntos cardinales. El poema «Moulin» viene también a dar testimonio al mismo respecto, según se verá en seguida. 
En cuanto al árbol, el mismo Eliade consigna que

una multitud de mitos y de leyendas hacen intervenir a un Arbol cósmico que simboliza el Universo, correspondiendo sus siete ramas a los siete cielos; un árbol o una columna central que sostiene el cielo, un árbol de la Vida o un árbol milagroso que confiere la inmortalidad a quienes gustan sus frutos.

Aunque no lo exprese Eliade en estos pasajes, es obvio que a esa definición se atiene el «Arbol de la Vida», cuyos frutos no le fueron permitido gustar al Adán del gran mito cultural de nuestro Génesis por haber ingerido el de otro árbol de significado contrapuesto y maligno que le condena a muerte. Será el primero el mismo "Arbol de Vida» que crece siglos más tarde en el centro de la ciudad celeste y mandálica -paradisíaca- del Apocalipsis, morada del «segundo Adán». ¿Y cómo no recordar a este propósito las palabras del poema "Adán», escrito por Huidobro en Santiago de Chile y publicado auténticamente en 1916, cuyo epílogo comienza de esta forma?

¡Oh Padre Adán! Arbol frondoso,

Arbol de maravillas y prodigios,

De actividades en reposo,

Arbol lleno de anuncios infinitos.

Arbol que llenó el mundo

Con sus innumerables frutos.

El autor de estos versos es el mismo Huidobro que ya en París esculpirá en el pórtico de la nueva literatura su célebre lema de Horizon carré: «Hacer un poema como la naturaleza hace un árbol». ¿No será éste acaso el árbol de Altazor? En todo caso, con precisión notable Huidobro dirá por tres veces en la penúltima página del Canto I de ese poema: «Silencio, la tierra va a dar a luz un árbol», para terminar dicho Canto I con estas tres líneas:

Silencio

Se oye el pulso del silencio como nunca pálido

La tierra acaba de alumbrar un árbol

¿Y acaso no parece Altazor este árbol de siete brazos o ramas?

No menos sorprendentemente se lee casi al final del poema "Adán», al terminar de referirse a la Torre de Babel, que considera a ésta como

El triunfal monumento de la ciencia Como un gran árbol con sus raíces fijo Aferrado en las entrañas del vacío. 
Por cierto, no es de creer que Huidobro estuviera pensando en el árbol de Babilonia que cobija a toda la tierra en el libro de Daniel (IV), pero no es menos cierto que coincide en gran manera con él. Babilonia siempre.

Por último recordaremos que, ya en 1913, en el tercer poema de Las pagodas ocultas, Huidobro había dedicado tres páginas a desarrollar el amor al árbol de cada una de sus propias vísceras y de sus miembros: «¡Oh árbol milagroso!». Mi corazón, mi cerebro, mi espíritu, mis ojos, mis oídos, mi boca, mi cuello, mis manos, etc., te aman. Para el pensamiento mítico no puede caber duda de la identificación total absoluta, que aquí se opera entre el poeta y el árbol por mediación del Amor.

Huelga insistir sobre el asunto. Son demasiadas coentrañaciones externas e internas para que puedan atribuirse a la voluntad deliberada del poeta de reasumir los símbolos culturales, cuyo significado, no sólo en Santiago de Chile, sino en París mismo, ignoraba, si no menospreciaba como poeta olímpico, aunque se interesase por la magia y el ocultismo, como los ignoraban de Mallarmé abajo todos sus compañeros. En líneas generales puede sostenerse que tales símbolos eran espontaneidad suya y que su reiteración corrobora su trascendencia. Lo que induce a pensar que el poeta se hallaba poseído por un «complejo autónomo» de orden, aunque en algunos aspectos en contraste invertido de significación trascendental tan honda como auténtica.

Que dicho personaje posidente se emparentaba con el anticristo de Nietzsche, autor del poema «Los siete sellos», es cosa que carece de incertidumbre, porque, independientemente de otras consideraciones, Huidobro mismo tuvo a gala confesar en Vientos contrarios haber escrito uno de los Cantos de Altazor en el cuarto que el autor de Zaratustra había ocupado en Silvana Plana. Se ha de advertir además que dicho poema de Nietzsche, donde se proclama siete veces la vigencia del anillo del Eterno Retorno, se asocia admirablemente con la afición huidobriana del molino en que se plasmó la figura estupenda del caligrama Molino, que gira, gira, gira, en las cuatro estaciones como un reloj que, al mismo tiempo que un «mandala» en movimiento, fuera una Cruz. No olvidaremos que, según lo indicado, la palabra Molino sale a relucir, como una alusión al Eterno Retorno, unas doscientas veces en otros tantos versos del Canto $\mathrm{V}$, como queriendo poner a prueba la resistencia del lector ante el embrutecimiento de semejante alarde.

En esta perspectiva, Altazor se nos transmuta en un instrumento cultural; en un molino de imágenes y de palabras, en un avión supersónico, en una nave cósmica. En él se concentra el espíritu que vería 
decantándose en la lírica occidental hasta el Simbolismo -así también en las artes plásticas - y se resumen los impulsos de los tramos primeros de su recorrido con la intención de proyectarlos a su verdadero fin. Porque, al menos desde el Romanticismo, toda poesía de raíces humanas profundas es escatológica: más o menos vive hipnotizada por razón de un fin. Dicho fin es en el presente caso, evidentemente, el otro y nuevo lenguaje, la médula de una Cultura Universal más allá de la Babilonia de nuestro siglo. A Altazor no le está consentido superar, por muchas que sean sus desorbitaciones, esta babélica situación preliminar. No obstante los aspavientos de sus molinos, es incapaz de transponer el espectro negativo. Ha de limitarse a dar fe precursoramente de la muerte del estado de cultura actual y previo, al modo del Vallejo de «en suma, no poseo para expresar mi vida sino mi muerte». El encumbramiento de Altazor finiquita en la disgregación de los signos vocales insignificantes, salvo en calidad de últimos suspiros. "Altazor, morirás», se le augura desde el principio. Nuestra Cultura, tal como es en sí y como se nos muestra representada por Huidobro y tantos otros, inclusive revolucionarios, no puede, mediante su ciega voluntad consciente como resorte último, pasar de ahí, de donde impera el anticristianismo de Nietzsche y su superhombre ambiguiísimo. Se ha de observar que el Surrealismo bretoniano, emanado asimismo del Simbolismo de Mallarmé, participa de la misma aspiración de ascender a la montaña en cuya cúspide se resuelva la contradicción de la dualidad básica en la lucidez del Ser Absoluto. Así, Breton ascendió, en un acto sintomático entre mundo y mundo, junto a su compañera, a la cima del Teide en $L^{\prime} A m o u r$ Fou.

También procede darse cuenta de que la solución tan ansiada desde los días de Baudelaire no armonizaba con la psicología radical y, por tanto, con las posibilidades creadoras de la lengua francesa. Radica ésta y florece en los niveles de la razón cartesiana, nucleada en el je individualista del fundamento corpóreo con detrimento de la imaginación impersonal. No era factible, por consiguiente, encaramarse por sus laderas a la cumbre de la transfiguración decisiva. «Me hubiera vuelto loco», confesaba Rimbaud con mucha razón a su hermana refiriéndose a sus desenfrenos juveniles. (Dijérase que prevía el doloroso caso de Antonin Artaud). Por idéntico motivo, tampoco a Vicente Huidobro, a la conciencia de Vicente Huidobro, le resultaba asequible la solución anhelada. Su Adán chileno se constituía en el absoluto de la razón científica y en la hipertrofia de un Ego individualísimo. Pero a pesar de que la estructura psíquica de la conciencia del poeta no le permitiera trasponerse a la altiplanicie paradisíaca, la calidad radioactiva de la imaginación 
que obraba en su circunstancia determinó la apertura del portón por donde fue alumbrado este altazórico objeto singular. Aunque éste no pudiera resolver positivamente y por sí mismo nada a la letra, acusaba por inducción, y en relieve invertido, la huella futura de otro lenguaje; de un lenguaje de más allá en el orden de la Cultura, susceptible de entenderse en otro nivel y proyectado por la circunstancia nativa de la persona de su autor al Nuevo Mundo. Lo cual significa, si nos aventuramos a definirlo así, la intervención de un destino genérico que se cierne en otras atmósferas universales, como en su limitada esfera personal pretendía hacerlo Vicente por medio de su personaje u otro-yo representativo.

Pero la identificación de Altazor con la persona de Vicente Huidobro invita a imaginar lo que en el dominio de la Cultura significaba este personaje tan doblemente fuera de lo común y tan mal estimados uno y otro por los próceres de la crítica al uso. Yo diría que Huidobro-Altazor es un índice cultural que, fracasado en cuanto a la realización en torno a su persona o existencia subjetiva, de cuantas maravillas presentía, en vez de convertirse en el Sujeto de la circunstancia nueva, se transformó en un Objeto; en un signo como el que nos dijo que él esperaba; en un objeto simbólico, indicador de las proximidades de aquello que se dispone a advenir. Es un signo precursor del Nuevo Mundo. Por su ascendencia familiar y por el significado social de su estirpe, Huidobro era un signo representativo de la corriente ennoblecida de la conquista española. Representa a la gente advenida de allende los mares al Nuevo Continente, un tanto a la manera como César Vallejo es un símbolo no menos representativo de la fusión de la naturaleza autóctona con el Espíritu cristiano de la cultura mediterránea. Vallejo presenta caracteres asombrosos de encarnación trascendental que no se advierten en la genialidad imaginativa del primero. Digo bien: genialidad. Porque nos guste 0 no nos guste a todos, Huidobro genio fue. Pero unidos ambos, el de Santiago de Chuco y el de Santiago de Chile, se complementan. Con uno y con otro nos encontramos en la Babel de la confusión de las lenguas, o sea, en las contigüidades del Verbo creador que transfigure nuestra conciencia de Ser. La crítica misma está, a mi entender, demostrando, con el testimonio de sus confusiones e incomprensiones, que pernoctamos mejor que vivimos en Babel, donde la infinita Poesía es suplantada por la Musa de las glosolalias.

A Vicente le estaba vedado, como al mar, rebasar cierta orilla, puesto que, identificado por constitución y deleite con el individualismo que sujetaba su conciencia a las estructuras europeas, era sensible a una gravitación de la que el transconsciente de Vallejo se sentía desvincula- 
do, libre, en virtud del Amor. Uno se asociaba filosóficamente con el Anticristo, mientras que el otro se confundía por el sentimiento con el Neocristo. Los últimos poemas del peruano, entre los que descuella el conjunto España, aparta de mí este cáliz, corroborados por las circunstancias seudofortuitas de su muerte, son indeciblemente reveladoras. Pero los dos, César Vallejo y Vicente Huidobro, abarcan representativamente, dentro del paréntesis de su inexplicable parentesco, la plenitud trascendental de América Latina. En ellos se simbolizan los dos principios culturales que se enfrentaron, lucharon entre sí y se confundieron a partir del siglo XVi en el seno de un solo lenguaje, lo europeo y lo autóctono. Sin embargo, ante la muerte patentizan sus caracteres particulares que se reflejan en sus estilos. Aunque en lengua castellana, Huidobro declamará su amor delirante de hijo a su «Madre Francia», a quien debe «la mitad más profunda» de sí (El hijo canta a la madre dolorosa). Por su parte, Vallejo se había apagado ya para entonces, en el instante cultural preciso y con la palabra definitiva en sus labios: «Me voy a España», rindiendo el Espíritu en el corazón de la «Madre España».

De otro lado, Huidobro había venido despojándose poco a poco de los artificios de un lenguaje de su imaginaria confección con sus luminosas sinfonías. Tras Altazor, inspirado ya por su desbocada indignación contra la muerte, compuso Temblor de cielo, donde el optimismo incontenible de su juventud se contempla en el espejo de la más abismática de las negruras. En cierto modo, todo en su vida ha venido torciéndosele. Ha cometido errores sin duda, aunque él no lo reconozca. Ha levantado polvaredas. Pero la adhesión de los de aquende y de allende le ha sido rehusada y las actitudes del contorno, por lo general injustas y con frecuencia mal intencionadas, han sedimentado en su corazón un sentimiento de amargura tal que, sintiéndose en la cruz, le ha inducido a escribir Las siete palabras del poeta. La Poesía misma, que en su esperanza lo era todo - «La poesía soy yo»-, se le ha tornado por el momento arquetipo inaccesible Isolda - reflejo del Eterno Femenino-, que a él le identifica con el moribundo Tristán. Oye clavar el ataúd del cielo, lo que supone corresponder, decía, a la muerte de Dios, pero que acabará desembocando

en el fin de los fines en donde un hombre colgado por los pies de una estrella se balancea en el espacio con la cabeza hacia abajo.

$Y$ añade en seguida:

Vivimos esperando un azar, la formación de un signo sideral en ese expiatorio más allá en donde no alcanza a llegar ni el sonido de 
nuestras campanas. Todo está al borde de la muerte. ¿No oyes clavar el ataúd del mar?

¿Oyes? Están clavando mi ataúd. ¿Oyes cómo clavan mi ataúd? ¿Cómo encierran la noche en mi ataúd, la noche que será mía hasta el fondo de los siglos? Soy lento para morir.

...

Sólo el ataúd tiene razón.

...

El cielo es lento para morir. ¿No oyes clavar el ataúd del cielo?

La identificación absoluta se ha verificado: Dios, el mar, el cielo, el sujeto poético se hacen uno en la muerte. Muere el "pequeño dios" infatuado de la literatura creacionista, amortajado en un derroche de imágenes y metáforas probablemente sin paralelo, algo así como en una especie de wagneriana necroapoteosis. A partir de allí, en un estilo de sencilleces impretenciosas, Huidobro pondrá al descubierto en sus poemas últimos las lámparas enternecidas de sus médulas.

También en este aspecto se aúnan, distinguiéndose entre sí, Huidobro y Vallejo, torturados ambos desde pronto con el problema fundamental del ser humano, su condena a muerte - que tanto había atormentado también a Rubén Darío-. Uno, Huidobro, para desgañitarse en sus umbrales, "porque soy protesta, insulto y mueca de dolor» (Canto I). Vallejo, para autoinmolarse en aras del espíritu colectivo a favor de la especie; para infundirse en la conciencia en masa del último y planetario Adán.

Se ha de repetir, a fin de hacer más evidente el sentido de la configuración, que la honda poesía moderna de Occidente, lo mismo que sus religiones, es siempre escatológica, proyectada a la prospección y conquista de su más allá. Los poetas se han empeñado, diríase, en ganar las tierras paradisíacas al mar, según lo intuido, en su adecuada coyuntura por el Fausto de Goethe -pensando, según se sabe, en AméricaA ello se dieron sus figuras más caracterizadas, para llegar unas tras otras al fracaso. Fracasó el Romanticismo en bloque, persiguiendo las alucinaciones que parecía brindarle el inmediato porvenir. Fracasó Nerval rebuscando pajuelas de nuevas luces entre las sombras mentales de la Vieille Lanterne. Fracasó Baudelaire en sus ansias de viaje al paradisíaco ultramundo. Fracasó Rimbaud estrepitosamente, abjurando de sí mismo y de sus compromisos de videncia, aunque dejara un reguero estelar que ha estimulado a muchos. (De ello doy yo mismo fe). Fracasó Mallarmé en sus pretensiones últimas al consumarse su naufragio en la Nada -que curiosamente resulta ser en castellano inversión anagramática de ADAN-, aunque deje flotando a la deriva para beneficio de algu- 


\section{H.}

nos robinsones los derelictos simbólicos de su nave. Fracasó en cierto modo Apollinaire, que murió incumplido en el preciso día de La victoria francesa, que no pudo ser la poética suya, por lo demás tan galófila. Fracasaron las desmesuradas ambiciones del Surrealismo y de sus figuras principales -entre ellas la desgarradora de Antonin Artaud-, no obstante las actividades pequeño-colectivas de su horizonte parisién. Fracasó Vicente, «antipoeta y mago», a caballo sobre el Clavileño en brasas siderales de su propia Muerte. Fracasaron todos en el derrotero del arquetipo dantesco, Ulises, de nombre tan entrañado a la realidad mediterránea de nuestros días, que en su búsqueda del más allá de Europa acabó engullido por el Océano a la vista de la "Tierra Nueva» (Infierno, XXVI). Revelación estupenda, por cierto, del espíritu poético medieval, puesto que dicha Tierra, dotada de una montaña altísima, resultó ser siglos más tarde el nuevo continente colombino o Continens $P a$ radisi.

Si Vallejo no se incluye en el fracaso general, se debe a que constituye un verdadero caso aparte. Nada se propuso en el orden de la literatura y sí en el de la Vida genérica, ante la que derramó por Amor su esencia propia de manera que, definiendo el significado de España que en él cristalizó sus trascendencias verbales, su fin significó la muerte metafísica de la Muerte.

Pero el fracaso de Huidobro lo fue tan sólo a medias, en cuanto a voluntad individual, por ser el suyo un fracaso creador que lo convierte en un signo positivo, plantado reveladoramente a la entrada del último trecho del camino por él -y por Dante- soñado y predicho. Toda su vida se la pasó Vicente definiendo a la Poesía como potencia absoluta en los más apasionados y sublimes registros de que su pretendida superconciencia o delirio poético de su imaginación se demostró capaz. Mas acabó por comprender al fin, siquiera relativamente, que sobre su esperanza se habían precipitado los ocasos de muchos siglos que expiraban para dar lugar al nacimiento de una humanidad muy otra. Sobre él se cerraban las noches de su poema «Edad negra», que, como luego se verá, resultó especialmente significativo. Y significativo en más de un aspecto. Que inclusive dio lugar a uno de los pequeños fraudes que a Huidobro, por vivir anfibiamente entre dos esferas de realidad, le eran más difíciles de evitar que a otras personas. Lo dio a conocer como inédito en forma extemporánea y como añadido en las dos últimas páginas de su Antología, firmada por Eduardo Anguita (1945), después de los textos en prosa y con la indicación: «Este poema es inédito y pertenece a las últimas producciones del autor». «Edad negra» parecía definir así en la mente del poeta su lírica anterior, a la vez que 
desempeñaba un oficio como de codicilo testamentario añadido in extremis para exhortar a la juventud a no seguir su ejemplo. Sin embargo, no era éste un poema inédito, puesto que había aparecido en el número de marzo-abril del año anterior en la revista mexieana Cuadernos Americanos. Pero como Huidobro supo precisamente por mí que Juan Ramón Jiménez lo había elogiado mucho, debió sentir el deseo de añadirlo a su Antología, presentándolo como desconocido hasta la fecha. Grata muestra de su ingenuidad.

Pero antes de aprovechar el significado que en cierta perspectiva consiente la intención admonitoria del último de sus versos, Guárdate, niño, de seguir tal ruta, estimo conveniente determinar en lo posible la excepcional importancia que la persona de Huidobro, tal como es, con sus más y sus menos, desempeña en la crisis poético-cultural de nuestro mundo. $Y$ con ese objeto, a fin de no dejar nada de lo que se presta a reprobación en lo oculto para solaz de las malas intenciones, he de recordar cierto episodio gravemente equívoco de su experiencia y al que no tuye oportunidad de referirme en mis evocaciones anteriores. Creo además que no debo reservarme para mi uso particular el texto, por demás impresionante, de la última carta que me llegó de Vicente, sólo tres meses anterior a su fallecimiento, documento que viene a esclarecer hasta el fondo el estado de espíritu que dio origen a «Edad negra». Estimo, por último, que, pues he tenido que desenmascarar sus embustes y artimañas, en cierto modo «juveniles», por no decir «infantiles», me es obligado declarar el juicio altamente favorable que, pese a tales imperfecciones, por lo demás candorosas y sin hiel ni detrimento para nadie, me merece a mí Vicente Huidobro dentro del cuadro de mi conocimiento de la realidad. Empezaré por esto último.

Entiendo que, con el conjunto de datos reunidos, nos asiste la razón para sostener que Vicente Huidobro fue el vanguardista máximo en este siglo en que empezó a hacerse patente la profunda y acelerada transformación que en todos sus aspectos estaba experimentando la Cultura occidental a partir sobre todo de la guerra del 14 . Consciente del oficio que en dicha transformación desempeñaban ciencia y técnica, Huidobro se alistó como voluntario en los conflictos de la circunstancia, y abrazó como profesión la de transformar el estado de la Cultura desde sus cimientos lingüísticos. Teorizó como nadie sus intuiciones acerca de la esencia y de los cometidos de la gran Poesía. Como nadie cultivó desde muy joven la técnica del caligrama y de la metáfora, adelantándose a los franceses, aunque éstos no se sientan inclinados a reconocér- 
selo. Y su imaginación, pese a los de aquende y los de allende, se lanzó a la vivencia de un espacio cósmico de sustancia metafísica como nadie, lo que le es mérito suficiente para que, por lo pronto, se le tenga en justicia como el más grande poeta cósmico del siglo.

Una vez que en su cerebro se encendió la creencia en los poderes de la Imaginación y de su presencia verbal, la Poesía, Huidobro se consagró a ella, rompiendo desdeñosamente en su vida particular con los privilegios de su origen. Si en contraste con los otros poetas en agraz renunció a las ventajas sociales de su nacimiento sin reservarse sino lo necesario para proseguir su empresa combativa, no fue para ser un gran poeta al estilo romántico, un lord Byron, por ejemplo, sino para ser, según se vio, el poeta presentido por Emerson, que no se ha dado todavía, el esperado de una época en que asomaba el nuevo Adán u hombre universal entre los escombros del mundo derruido por la ciencia. Romanticismo también sin duda, pero indicativo de una vocación auténtica, indiferente a cuanto no fuera el triunfo por su mediación heroica de los valores universales, novísimos. Desde muy joven venía consagrado al servicio de una voluntad que sentía ser suya en virtud de la identificación existente entre su personalidad y su destino. Por ende, todo fomentaba el desmedido crecimiento de su Ego, que en tales condiciones, y en complicidad con su imaginación desenfrenada, no tenía más remedio que sentirse inconmensurable. Llegó a decir: «Para mí no ha habido un solo poeta en la historia de nuestro planeta» ( $E l$ creacionismo). Su figura no entra por estas razones dentro del concepto consuetudinario de lo que es un Poeta, siendo éste el porqué no fue ni estimado ni comprendido. ("Comprendido habría sido muy otro. Pero no pudo ser, acaso no debió ser». Irreparable, nada es irreparable). Por no caber dentro de esa noción vulgar, comparte con Vallejo la vivencia extramuros del lenguaje.

Ya sabemos que, desafiando en el orden práctico de la conducta, las discreciones de la razón teórica, Vicente cometió la temeridad de contraer matrimonio en edad muy temprana y de trasladarse a París en plena guerra con su mujer, de la que estaba prendado, y de sus niños. Tal vez la desaparición de Rubén Darío en febrero de 1916 le invitó a recoger su antorcha. Desde ese año al 24, su historia nos es conocida: su instalación en el cogollo artístico de porvenir más selecto de Francia; sus diferencias con Reverdy, Guillermo de Torre y compañía cuando a éstos les empezó a incomodar para sus fines y ambiciones la personalidad del chileno. Son sabidos sus trajines misioneros en varias ciudades europeas. También hemos recordado la aventura de su presunto rapto por haber augurado el fin del Imperio británico, en lo que su intuición 
demostróse al cabo de los años ser notablemente profética. Pero aquí, en este preciso punto, se inició un nuevo período de su vida, que dio lugar a otro nuevo rapto del que Vicente no fue víctima, sino autor responsable. Lo referiré porque me es dado añadir a los conocidos algunos pormenores y porque estoy convencido de que es preciso ventilar a fondo todas estas incidencias equívocas para alcanzar el meollo de su verdad poética.

El 4 de marzo de 1925 Vicente se embarcó de regreso hacia Chile con su mujer e hijos, en compañía de su madre y hermanos, que habían venido a París de temporada. Su propósito, me escribía desde Panamá, era estar de vuelta «en octubre lo más tarde». Pero al poco de pisar su tierra se dejó tentar por el demonio de la política en un nivel de acción agresiva, alentado por los estudiantes, cuya Federación lo postuló como candidato para la presidencia de la República. Esto en Francia se interpretó, me consta, como evidencia de su irresponsabilidad y favoreció su desprestigio. De otra parte intervinieron en su experiencia los hados conducentes a su enajenación. Sobre el supuesto de que a una persona de sus condiciones intelectuales le está todo permitido y de que cuanto más estruendoso sea el escándalo mejor para su sentirse ser en el mundo, lejos de poner freno a un inicio de enamoramiento con una jovencísima concuñada suya, del sector de familias más encopetadas de Chile, contesta a las dificultades que se le interponen con un desaforado poema, «Pasión y muerte», aparecido a plena página en La Nación de Chile en ocasión de Semana Santa, cuya lectura me dejó a mí estupefacto:

Hace unos cuantos meses, Señor, abandoné París Un extraño destino me traía a sufrir en mi país.

La causa de su sufrimiento atroz, como víctima nada menos que en la Cruz del Gólgota, era la mencionada jovencita — «acaso la más triste, sin duda la más bella»-, con la que, contra la oposición natural de sus respectivos familiares, pretendía establecer relaciones profundas. Los acontecimientos de su «extraño destino» se precipitaron, posiblemente gracias a ese alegato seductor. Respecto a mí, fue aquel un año de silencio, hasta que el 1 de septiembre recibí un telegrama suyo desde Santander, en España, anunciándome su llegada a París al día siguiente por la estación de Montparnasse.

Me cuenta. A la joven, de nombre Ximena, la han internado en un colegio, y él, amenazado de muerte, ha tenido que escapar por respeto a la tranquilidad de su madre. Viene también a levantar definitivamente el apartamento en la calle de Victor Massé, inocupado desde hace año y 
medio. Una semana después su madre llega a París, la marquesa de Casa Real, de la que recibo una esquela invitándome, por indicación de su hijo, a que me acerque a saludarle. Ha viajado con el exclusivo objeto de proteger a Vicente de los hermanos de Ximena, decididos a perseguirlo hasta el final con intenciones malhechoras. El escándalo familiar ha sido mayúsculo. De un lado, su mujer, sus hijos, de quienes se ha desentendido. De otro lado, la familia de Ximena, padres y hermanos, parientes suyos. De otro, su familia propia, sus hermanos y hermanas - su padre no quiso volver a verlo- Por último, el escándalo que, con reciedumbre de terremoto, sacudió el baluarte de la gran burguesía chilena. Procuré tranquilizarla en lo que pude.

En pocas semanas amainó un tanto el turbión. Vicente permaneció en París unos meses, liquidó su apartamento y partió para Nueva York, donde residió algo más de un año e intentó ganarse los favores tan codiciables del cinema. Otra vez silencio. Pero en la primavera de 1928, sin previo aviso, golpeó una mañana la puerta de mi apartamentito parisién en compañía de una joven bellísima. Con habilidad consumada había desde Nueva York dispuesto el rapto de Doña Inés. Una vieja sirvienta les había servido de agente de enlace y mantenía viva la comunicación. Viajó a Santiago de incógnito. Salió un día Ximena del colegio para no recuerdo qué diligencia natural, dentista o algo así. La esperaba un automóvil, que de inmediato emprendió la fuga hacia la frontera argentina. Vicente disfrazado con un sombrero hasta las cejas, anteojos oscuros y bigotes postizos. Aunque fueron seguidos muy, muy de cerca, consiguieron ponerse a salvo y llegar a París. Con lo cual se inició para Vicente una etapa distinta y en algunos aspectos literarios bastante fecunda, aunque tal vez en niveles distintos de los anteriores. En el mes de junio me encargó que le consiguiera en España dos libros sobre el Cid, cuya «hazaña" había empezado ya a componer, uno de los cuales era el extenso poema de José Zorrilla.

Por entonces alquiló Vicente un pequeño apartamento amueblado en el 16 de la calle Boissonade, cerca del carrefour de Montparnasse. Vivió en él en forma muy ajustada, iniciando a Ximena en las costumbres de la ciudad. El mismo cuida la adquisición de comestibles como un ama de casa económica que administra con parsimonia sus centavos y sin permitirse más extras que los establecidos con cautela previamente. Instituyó la costumbre de recibir allí los sábados a algunos amigos, escritores y artistas. Por cierto, Vicente fue siempre sobrio. Ni entonces, ni antes, ni después, bebía ni se dopaba. Escribe, escribe...

Confesaré que aquel episodio no despertó admiración y menos entusiasmo en mí. Mi reacción podrá atribuirse a la sensibilidad burguesa 
de quien, no obstante haberse desprendido del medio que desde su cuna lo envolvía y de juzgarse liberado, conservaba reliquias de la moralidad de su niñez. Sin embargo, entendía yo que la nueva humanidad a que aspirábamos poéticamente exigía la adhesión a principios y actitudes moraies más rigurosas que las del estado que juzgábamos aborrecible. Lo que me pareció ajeno a todo sentimiento de equidad es que, para satisfacer Vicente los dictados de su egolatría, no vacilase en causar dolores intensos y hasta intensísimos a muchas gentes que personalmente no eran culpables ante él de nada, en especial Manolita y sus hijos. Que una cosa era el estado social hereditario y otra los sentimientos de las personas vivas. $\mathrm{Y}$ además es obvio que existen modos y modos. Seguimos viéndonos, siempre muy amigos y hasta quizá más asiduos que nunca en algún aspecto, porque me necesitaba más y porque entre la joven Ximena y la también joven persona que al poco se convertiría en la madre de mis hijos se establecieron en 1929 buenas relaciones de amistad. Vicente y ella actuaron como testigos en nuestra unión. Pero algo muy profundo de mi estimación por Vicente se había lesionado -entiendo que por suerte, ya que acabé así de liberarme--. Además había yo comprendido que su sensibilidad ante la desdicha ajena era nula.

Sólo muchos años más tarde llegué no a justificar su proceder, que moralmente sigue pareciéndome insostenible, mas sí a comprender su por qué en otro nivel y orden de valores. Fue para ello necesario que llegase a darme cuenta de la intervención en el fenómeno de algo tan imponderable y sutil como lo es el de un extremoso destino congénito. Arrastrado Vicente compulsivamente por su voluntad - ihasta qué grado era suya? - de ser el extraordinario Poeta que reclamaba la nueva época, había empezado por desentenderse del mundo de su origen cuando se trasladó a Europa en 1916. Pero diez años más tarde hubo de sentir que se hallaba prendido entre los lazos sentimentales de su familia personal, de su esposa e hijos, que, no obstante las libertades que en esta cuestión se permitía, lo mantenían enmarañado. Su rebeldía intrínseca, su voluntad de ser el Poeta sin ataduras ni frenos, tuvo que colocarle en trance de que los acontecimientos en cadena de reacciones le impulsaran a desconocer los vínculos que le prendían a los suyos, así como al medio chileno de su origen. Rompió más a fondo esta vez con todo. Psicológicamente el fenómeno se entiende. El mismo escribió al poco: la poesía «existe con su vida propia, con su destino, con su fatalidad, y ella aplastará a todo lo que pretenda obstruirle el camino y su marcha imperativa, porque ella es necesidad orgánica y necesidad cósmica» (Prólogo a Defensa del ídolo). Pero ¿y la solidaridad humana en el 
orden del Espíritu, que es Amor?, le hubiera argüido Vallejo. De este modo llegó a perfeccionarse en él la figura del Poeta energuménico, dotado de facultades imaginativas refulgentes, pero relegado al oficio de precursor, esto es, de aquel que anuncia a sabiendas o semiconscientemente lo que se dispone a venir tras él. Su propia constitución subjetiva le incapacitaba para transponer en el orden esencial lo que le separaba de sí mismo, o sea, del "paraíso» adánico. En esa posición y lugar quedó modalizado, poeta faber, en el nivel yo diría de la mente helénica, fundamentalmente corpórea, obsesionado por su muerte, sólo digno de acercarse por sus propios medios humanos al umbral de esa puerta que «sólo Dios lo traspasa» (Bécquer, LXXIV).

Contrajo algo después matrimonio con Ximena según el rito mahomético, cuya fe religiosa hubo de aceptar con tal propósito. No tardó mucho en adherirse políticamente al partido comunista, aunque al poco no pudiera soportar que le encargaran adoctrinar una célula de zapateros. Hacia entonces, sobrecogido por el terror de la guerra que presentía avecinarse, Vicente se empeñó en que un grupo de amigos nos trasladáramos a ver los toros desde la barrera africana de Angola. Recogió informaciones en el consulado portugués, leyó libros y durante no pocas semanas estuvo machacándonos con el proyecto. Nadie se dejó seducir. Hacía poco que había yo regresado del Perú y aún tenía el aliento entrecortado por mis aventuras, que distaban de haber llegado a término. Tampoco se sintieron conmovidos Tzara, Lipchitz, Arp, Vargas Rosa, Pilo Yáñez, etc. Se marchitó el proyecto. Pero en cambio el poeta vertió su emoción en las páginas de La Próxima.

En octubre de 1932, Vicente y Ximena salieron de París, él vestido de proletario, con un chaquetón y pantalones de pana. En Barcelona recogió unas parejas de ruiseñores que se proponía aclimatar en Chile. Y no tardó mucho en dar a la imprenta allí su libro Papá, o el diario de Alicia Mir, supuse que para volcar sobre su mujer la culpa de su abandono. No me privé por mi parte de criticárselo a causa de Manolita y de sus hijos ni me dejé convencer por sus débiles negativas.

Lo que no imaginaba Vicente por entonces es que, unos años después, Ximena, tras haber tenido un hijo suyo, lo abandonaría para unirse a uno de sus discípulos. Siendo el orgullo quizá la espina dorsal del carácter de Huidobro, este último contratiempo significó para su hipertrofia demoníaca una suerte de desastre. Si muchas de sus contrariedades anteriores habían venido limando las alas de su euforia constitucional, con la que compensaba su saberse condenado a muerte, el fallecimiento de su madre, quien constituía en el orden del sentimiento su talón talismático, y las guerras de España y después de Francia, aca- 
baron por aflojar su tercera columna, de madurarlo. Volvió a Europa en 1944 -antes había estado unos tres meses, cuando el drama español-. Se unió al ejército francés, siendo herido en la cabeza, como Apollinaire. Entró con las tropas libertadoras en Berlín, trayendo como botín de guerra un teléfono personal de Hitler. Regresó a Santiago en 1945 unido a su tercera esposa, una chilena espléndida que descubrió en la Embajada de su país en Londres.

Desde entonces todo le fue a Vicente cuesta abajo, hasta el final. Dedicó el sentimiento de su madurez a la composición de sus poemas posteriores a $E l$ ciudadano del olvido, ya de por sí muy ablandados. Lejos de él, las imágenes un tanto grandilocuentes mezcladas con los sentimientos que en este último libro procuraban disimular su fracaso. Sus Ultimos poemas son más emocionados, doloridos y aun sencillamente grandiosos. Imagino que su problema con Ximena debía de venir arrastrándose quizá desde el 42 o 43.

Pero la verdadera sustancia del estado subjetivo que vivía Huidobro en sus últimos tiempos se revela en el texto de la carta antes aludida que me escribió el 24 de septiembre de 1947. Las lobregueces acumuladas en Edad negra constituyen un monumento impresionante sin duda. Pero son parte de un objeto de creación artística que, por éste su carácter, vicia en alguna manera la plena autenticidad de su testimonio. En la carta tres años y medio posterior, el poeta se manifiesta sin espejos ni veladuras, tal como se siente en cuanto ser humano. De ella extraigo los párrafos siguientes:

Los hombres aman lo maravilloso, especialmente los poetas, y lo maravilloso ha pasado a manos de la ciencia. Los poetas se sienten tan huérfanos de maravillas que ya no saben qué inventar. Esto sólo prueba que la poesía murió, es decir, lo que hasta ahora hemos llamado poesía. Seguramente vendrá otra clase de poesía, si es que el hombre necesita de ella. Nosotros somos los últimos representantes irresignados de un sublime cadáver. Esto lo sabe un duendecillo al fondo de nuestras conciencias y nos lo dice en voz baja todos los días. De ahí la exasperación de nuestro pecho y de nuestra cabeza. Queremos resucitar el cadáver sublime en vez de engendrar un nuevo ser que venga a ocupar su sitio. Todo lo que hacemos es ponerle cascabeles al cadáver, amarrarle cintitas de colores, proyectarle diferentes luces a ver si así da apariencias de vida y hace ruidos. Todo es vano. El nuevo ser nacerá, aparecerá la nueva poesía, soplará en un gran huracán y entonces se verá cuán muerto estaba el muerto. El mundo abrirá los ojos y los hombres nacerán por segunda vez o por tercera o cuarta. 
He aquí la verdadera «confesión inconfesable» de Vicente Huidobro, amarga hasta las heces. La Poesía en la que había creído fanáticamente, confiriéndola poderes sobrenaturales, prácticamente absolutos, y consagrado a ella la totalidad de su vida, está muerta. Mas como ella era su razón de ser, el poeta es quien está muerto en realidad. Y si él la llora moralmente, es porque ella le está a él llorando, «porque yo soy el muerto que quedó en el camino» (Madre). Es inútil que a su cadáver le cuelguen cascabeles ni le aten cintajos de colores bajo una diversidad de luces para ver si así se conmueve y emite algunos sonidos, como él da a entender haber estado haciéndolo. Se ha llegado al fin. No al fin del Universo como su sentimiento poético-escatológico había pronosticado en Ecuatorial durante la guerra y después en Temblor de cielo. Mas sí al término de un amplísimo período humano, precursor por fuerza de una en su sentir remota edad futura. Y quizá se ha llegado al estertor del sujeto típico correspondiente a ese inmenso período, personificado en su propia vida de poeta trunco.

De no ser por éste, su concreto reconocimiento precursor, el fracaso de Vicente Huidobro, salvo en lo literariamente humano, sería completo. Pero en ello se diferencia ventajosamente de los fallidos impulsos poéticos occidentales del siglo XIX, de los creacionistas de Nord-Sud, y en especial del de su émulo Pierre Reverdy, que poetizan en un seudocreacionismo literario a nivel de superficie. El creacionismo de Vicente Huidobro es de muy otra categoría y profundidad, puesto que se refería al Verbo del Creador del Génesis, o sea, a la raíz ontológica del Mito de los mitos. He aquí la tragedia huidobriana sin atenuantes. Al morir el poeta, el Ser Creador ha muerto, según su dictamen anterior, en la buella de Nietzsche. Se encuentra el lírico atrapado como un ave prodigiosa entre las garras mentales de este último a la espera de que en un lejano tiempo «volverá a dar vuelta el anillo del caos» (Irreparable, nada es irreparable), trayendo consigo el nacimiento de un "nuevo ser».

En esta crucialísima coyuntura nietzscheana volvemos a encontrarnos con Vallejo, puesto que ambos, Huidobro y él, hicieron suyo el lema de Zaratustra: «El hombre es algo que debe ser superado», o sea, el propósito de establecer un estado de superhumanidad. Ello permite enunciar similitudes y diferencias entre ambos poetas sudamericanos, que, a mi juicio, son los verdaderos grandes poetas del continente sur y de la lengua por pertenecer a un nivel de más alta calidad trascendente que los otros. E inclusive del siglo, puesto que en ambos se plantean y viven los problemas universales de la naturaleza humana como auténticos índices representativos del Nuevo Murido. Los eurohispanos, no obstante las inclinaciones de Unamuno y aun de Machado hacia los 
valores del ser cristiano y al misticismo tardío de Juan Ramón Jiménez, se pliegan a los sentimientos y tratamientos circunstanciales en estratos subjetivos e inmediatamente sociales. Todos se ubican en el círculo de las resignaciones de campanario, cuando no en el del «Sálvese el que pueda».

Huidobro y Vallejo constituyen la verdadera vanguardia de la hispanidad. Vástagos del hemisferio sur, ambos se educaron religiosamente conforme a los símbolos de la tradición judeo-cristiana, de cuya literalidad se manumitieron cada cual por su cuenta; Huidobro, por razón de sus mecanismos intelectuales, algo más que de su literalidad; en cambio, Vallejo no desistió del sentimiento, sino que lo ahondó y refinó en determinada forma. Entre los predecesores de su ámbito, ambos fueron admiradores sin merma de Rubén Darío, cuya conciencia vibraba en clave análoga. Ambos se encararon desde niños con la inmensidad del Pacífico; Huidobro desde su costa ilustrada; Vallejo desde el mirador altísimo de los Andes, impregnado además por la grandiosidad del cielo estrellado. Ambos se insurgieron contra el destino mortal del hombre, sin que Huidobro, aunque enfurecido por la idea de su muerte, entreviera la posibilidad de intervenir en la abolición de la de todos. Idénticamente a Nietzsche, Huidobro se deslizó por los declives de su persona individual, con su voluntarismo indomeñable, con su «soberbia de monstruo arcaico» (Veo el universo reducido). No podía darse cuenta de que el planteo de su conciencia, fundamentalmente físico y de sexo masculino, le inhabilitaba para resolver por sí ante el Ser de la Vida, un conflicto metafísico como es el de la Muerte. Idénticamente al germano, su estructura básica se hallaba en sintonía con el individualismo del concepto helénico acerca del hombre y de su razón filosófica, de manera que su Adán se decinía como una criatura científica, fruto de una naturaleza materna, en lo que coincidía con Mallarmé y el conjunto de los poetas europeos. Su línea era la sádica de Caín. Vallejo, en cambio, si bien adosado al sentimiento de la maternidad, era poseído por el Espíritu colectivo y su razón práctica; se afirmaba en el camino místico de su negación individual o disolución en el Amor de todos (Abel). Se concebía en él, en progresivos estratos, la posibilidad de que, superando en cierta forma al Jesús histórico, el Ser absoluto transmutase teleológicamente los destinos universales. Huidobro concebía el bien como el triunfo de su personal dictadura poética, mientras que para Vallejo, más humanamente profundo y genéticamente más universal en virtud de su abolengo indígena, el bien sólo podía ser la razón de todos contra la fatalidad genérica de la Muerte, ante lo cual sus intereses particulares se desdibujaban hasta desaparecer por completo. 
En su inclinación a resolver las injusticias de la existencia humana en el campo social, ambos, cada cual por su sendero, adherirían a la causa del comunismo militante. Aunque Huidobro se desentendiera de su práctica con posterioridad, dejó publicados en 1935 los siguientes conceptos suficientemente claros para que no requieran explicaciones que los dignifiquen:

Hoy día considero que no tengo otro deber que servir a lo único que puedo servir sin avergonzarme de mí: la revolución social.

Pienso que el deber de todo escritor es acercarse al proletariado, estudiar sus problemas, sus luchas, sus reivindicaciones y aprender humildemente a servir la gran causa de la revolución, o sea, de la justicia. Esto, aunque le pese al señor Neruda y sus compinches, que son tan finos y tal sutiles que la vista de un obrero les ataca los nervios.

Confieso todas mis taras burguesas, pero tengo la esperanza de irlas corrigiendo día a día. (De Vital, núm. 2, enero 1935).

Ambos se embanderaron apasionadamente en las huestes de la República española cuando el terrible trance de su tragedia popular, a la que dedicaron sus poemas en 1936-38. Pero Huidobro estaba junto a ella en modo quizá algo más externo y parcial, puesto que parecido y aún más profundo sentimiento manifestó por Francia (El Hijo canta a la Madre Dolorosa), mientras que la entrega de Vallejo a la Madre España fue integral, hasta compartir su misma suerte, idénticamente a la del hijo en las entrañas cuando la madre perece.

Los dos eran poetas de destino en el orden universal de la Cultura humana, entendida ésta como una entidad antropológica dotada, como el Adán del Gran Mito, de una razón esencial y, por lo mismo, exento de la «culpa» hasta que, al saberse mortal en razón de su carne y hueso, el Ser Espíritu lo condena a muerte. Ambos son geniales, pero con significados distintos y, si bien se mira, complementarios: el de Vallejo, en situación más general y sublime; el de Huidobro, más imaginativamente desorbitado y engrandecido.

Para entender satisfactoriamente esto último se requiere una explicación.

Al entrar en poesía, Huidobro se incorporó a la corriente medular y teleológica de la poesía europea de vanguardia. Y una vez instalado en ella, su ambición original le impulsó a situarse en su primera línea, con intención de proyectarse y proyectarla creadoramente a su lógico más allá. «Al desplegar las alas / él mismo no sabía qué vuelo era su vuelo», confesaría en $E l$ paso del retorno. Se había embarcado en el 
destino de fin de mundo de dicha poesía occidental. $Y$ al proponerse conseguir lo que no había podido lograr Mallarmé, quedó aprisionado en la imposibilidad de encontrar más salida que la de la Nada, por estribar en su mismo nivel consciente. Cierto es que el estado de «superconciencia» a que Huidobro se refiere en sus manifiestos definía su aptitud personal a situarse fuera de sí, en una especie de trance imaginativo que le facilitaba el vuelo en una estratosfera de altitud intermedia que, en el fondo, y a la vez que daba de sí una producción que algún día tendrá que estudiarse poema a poema y verso a verso con la atención que merece, le valía para engañarse a sí mismo, mientras ello fue posible.

Vallejo en cambio, al permanecer por sus convencimientos personales ligado a la tierra adánica de los muchos, cuando se negaba caritativamente a sí mismo en bien de todos, abría las puertas de su sentirse ser a otra sustancia psíquica, superconsciente y cualitativa que por el sentimiento se difundía en su conciencia, siendo la voluntad de su persona poseída en cierto modo y medida por Otro, según lo documentan estremecedoramente sus poemas últimos.

Se ha de insistir en que Huidobro y Vallejo son poetas de destino, de un destino certificado por sus afanes enajenatorios. Con ello se significa que eran más que exponentes por reflexiva y calculada conveniencia de los impulsos hacia el futuro de la humanidad; más que abogados defensores. Ambos eran impelidos por sus respectivas constituciones físicas y psíquicas, así como por las circunstancias exteriores en que, bajo el signo del Azar, se vieron envueltos y por las respuestas de cada uno a las mismas. En lo tocante a Vallejo, ésta es cosa que no debiera ignorar nadie que examine el fenómeno de su parábola existencial con pulcritud y, por disparatado que parezca, a partir de su infancia. Desde niño se vio arrastrado en un flujo teleológico que, sorteando escollos de varia naturaleza, fue a rendir su vida el 15 de abril de 1938 en el corazón de la Madre España.

En suma, ambos eran personajes de un contexto dramático en el que intervenían con mayor o menor independencia aparente, aunque llevados por el juego de las corrientes físicas, psíquicas y espirituales, etc., de la Creación universal. En este aspecto, el Creacionismo de Huidobro, culminando sobre el francés, atestigua con perfecta adecuación la índole del proceso en que el chileno vivía involucrado.

Sujeto sin sujeción, Huidobro pretendía, dentro de ese drama, revelar personalmente al Ser suplantándolo, es decir, revelarse a sí mismo en cuanto supersujeto absoluto o casi, empresa psicológicamente absurda por las razones expuestas. El Ser es incorpóreo e irrepresentable, 
aunque otra cosa pensasen los griegos. Pero esa su misma voluntad, no cohibida, era algo más que indicio, relativa prueba de que el Ser de la Cultura, llamémosle así, se revelaba en forma subordinada a través de él, que en realidad era su documento. En Altazor, con el concurso de las estructuras fundamentales de orden sociocultural que se esbozaron en su análisis, patentízase que la conciencia positiva del poeta no es sino un aspecto de la subjetividad del fenómeno creador, una secuencia melódica en el inmenso e inextricable fluir de la suprema sinfonía.

Pero, de otra parte, este poema revela al exterior que la razón que a Huidobro le asiste en sus arrebatados parlamentos es la del lenguaje, como en realidad lo había sido desde el comienzo de su experiencia, según dan de ello fe sus caligramas espontáneos de 1913. Una vez en Francia, no tardó el poeta en comprender que el problema esencial de la poesía moderna era el del lenguaje, o más bien del superlenguaje codiciado por Rimbaud, Mallarmé y seguidores. Sobre todo que al pretender transferirse, como pregonaba, del nivel del Hombre-Espejo al del Hombre-Dios, evidenciábase la indispensabilidad de articular otro lenguaje de más sublime naturaleza que el conveniente para el trato de los humanos entre sí. Esto explica no sólo la aventura de Altazor, sino el desarrollo gradual que experimentó el estilo de la locuacidad huidobriana. Mas por tener planteado el poeta su problema esencial sobre la convicción de su ser individuo, le era imposible concebir que dicho lenguaje superior tenía que ser de orden doblemente colectivo, puesto que la naturaleza del hombre, dotado de la facultad del lenguaje, ya colectivo de por sí, sigue siendo colectivo en otra especie de idioma. De manera que no cabe esperar de ningún poeta, ni de ningún científico, ni de ningún sacerdote que sea, por su decisión, quien lo pronuncie. ¿Cómo aceptar en el seno del extremo individualismo de nuestra época que existe ya desde siempre en la humanidad un lenguaje de registro superior al conjunto de los fonéticos utilizados en nuestra cultura babélica, es decir, el lenguaje de los Mitos auténticos que en realidad constituyen un lenguaje ideoimaginario? Me refiero no a los mitos confeccionados por un individuo aislado como recomendaba Platón a los poetas y los intentó fabricar él mismo, sino a los Mitos esenciales de los pueblos, en los que se expresa el contenido de su ser histórico o de su destino en las sinuosidades de ese laberinto contorsionado de la creación histórica. Y muy especialmente dentro de él el cuerpo mítico-trascendental de nuestra Cultura.

Sin temor a incurrir en el desdén conmiserativo de quienes lean estos conceptos, no ocultaré que, tratándose como se trata aquí de situaciones de extrema ruptura y de la búsqueda de un lenguaje de trascen- 
dencia superior en el seno mismo del lenguaje, lejos de estar fuera de razón, es, a mi juicio, indispensable que, al referirnos a esa crisis de ruptura con motivo de las actividades de extrema vanguardia poética, tengamos que recurrir a conceptos categóricos diferentes a los que vulgarmente se llaman naturales. Precisamente, la lógica más estricta induce a dirigir nuestro interés hacia las categorías poéticas y, en el caso especial de Huidobro y compañía, a las específicamente creadoras. En el coto cerrado de nuestro pensamiento occidental, la conciencia reinante se ha apropiado para sí del horizonte del futuro, como si lo esperable del mismo no correspondiera a un peldaño o agencia de orden superior, según lo ocurrido en la Tierra desde el comienzo de las sucesiones orgánicas, siendo así que las formas de mayor complejidad se presentan mutacionalmente de por sí cuando se han reunido las múltiples condiciones para su aparición (... peces, anfibios, reptiles, aves, mamíferos, primates, hombres...).

Sobre este paradigma axiomático se ha de imaginar que el conflicto que se acusa en la mente de los poetas de vanguardia, y no en la de los profesores, ni en la de los políticos, militares y sacerdotes de cualquiera de los sistemas en curso, ni por supuesto en la de los presuntos críticos literarios, ha de resolverse por el ángulo mental que a aquéllos los acucia. Indirectamente, Huidobro dejó esbozada esta misma convicción en el artículo de sus Manifiestos, que dice: Necesidad de una estética poética compuesta por los poetas.

Ciertamente, la gran incógnita del futuro parece sugerir a la conciencia de nuestros días augurios de providencia poética o de revelación. Pero ¿cuántos serán los pensadores con algo que perder que en nuestro siglo de racionalismo a ultranza se atreven a sostener la legalidad superracional $\mathrm{y}$, por tanto, la posibilidad de alguna revelación sustancial? Filósofos hay de gran linaje que la dan por buena como característica de la naturaleza humana, rica en intuiciones en tiempos idos, pero que se insurgen en defensa de sus prerrogativas antropocéntricas contra la posibilidad de una revelación actual, o sea, contra la operación de un Espíritu Imaginativo Universal que no sea el cultivable por la razón filosófica o científica en las laderas del pensamiento puro o teórico. Esta es actitud que se explica bien, porque fundada la estructura de los pensadores en la realidad de la existencia física de los individuos e instalados sobre las ruinas de la Teología medieval, se hallan convencidos de que, en el mejor de los casos, la revelación se extinguió con Pablo de Tarso junto con los Evangelios, y a lo más con el Apocalipsis, si es que se arriesgan a pronunciar su nombre. No se preguntan si no sería factible que la luz reveladora penetrara en la conciencia genérica por 
otros ventanales básicamente colectivos, puesto que el Verbo, en el que toda ultrarrazón tiene que fundarse, es función colectiva por naturaleza. Pero en la perspectiva de su óptica, siendo el lenguaje una sustancia colectiva, su manifestación simbólica tiene por fuerza que sustanciarse mediante su personificación en la conciencia de una voluntad individual, en soporte de lo que ellos mismos se sienten ser como individuos en el seno de la Cultura. Lo cual es un contrasentido determinado por el carácter de nuestra constitución cultural.

Si desde hace ya más de un siglo se merodea en torno del deseo de un lenguaje esencial, propio de una Cultura nueva, ha de ser porque se está dando a insabiendas testimonio de la gravitación cada vez más próxima, porque más ansiada, de otro lenguaje, de otro Verbo, si no del Verbo humanamente impersonificable, invisible, porque al Ser ni el ojo ni la inteligencia humana lo pueden objetivar, siendo la poesía el orden adecuado para su manifestación, como lo fue en los tiempos remotos de las escrituras proféticas y reveladoras. Se advierte además que, por la gran importancia adquirida a fines del siglo pasado por el Simbolismo, escuela poética de la que derivan los movimientos de vanguardia y toda vez que los símbolos son la sustancia del lenguaje, su misma presencia invita a comprenderse como un síntoma cultural de la quizá ya inminente comparecencia del Verbo.

En función de lo cual, no parece que pueda tildarse de disparate sostener que la tendencia de la Poesía occidental a inventar otro lenguaje, prolongada en nuestro idioma por Huidobro, es una manifestación por otras vías de la urgencia de la revelación lingüística de ese estado humano superior que desde el Romanticismo, cuando algunos pensadores destacados sostenían la necesidad de una nueva revelación, se desea hic et nunc. Lo que ha venido pretendiéndose es la transposición a la realidad terráquea de las creencias esperanzadas en la supernaturalidad post mortem de las personas individuales, cosa que, a fin de cuentas, podría convertirse en el post mortem de un estado de cultura con sus vísceras y sagrados utensilios. Diríase que Huidobro estaba debatiéndose delirantemente, prendido en esta tela arácnida que era incapaz de rasgar por hallarse establecida como esqueleto en su persona misma.

En este orden de realidades, ambos, Rimbaud y Mallarmé, se refieren, cada uno a su modo, al Verbo esencial o Lengua de las lenguas, concepto que en el poeta sudamericano que prolonga su impulso, asume, a la vez que formas más sensuales y esplendorosamente diversificadas, una fisonomía metafísica más concreta $y$ concluyente. Porque en Huidobro dicha entelequia se presenta entrañada al Mito esencial de nuestra Cultura, que en la Historia se ha comportado como columna vertebral 
en razón del Ser único, o sea, Mítico Creador del Universo mediante su Palabra.

En la experiencia de Huidobro resulta ser ésta una realidad evidente desde que su creacionismo se halla referido al del Creador del Génesis por una de sus puntas, y por la otra, a su proyección terminal o finalidad apocalíptica, puesto que él mismo sacó a relucir sus símbolos sustanciales, el Alfa y la Omega del alfabeto en que se simboliza. Lo hizo primero en Ecuatorial con referencia al fin de un período humano extensísimo, y después en los términos antes recordados de Total dirigiéndose en vejamen a sus compañeros: "Habéis perdido el sentido de la Unidad, habéis olvidado el verbo creador... El verbo cósmico, el verbo en el cual flotan los mundos. Porque al principio era el verbo y al final será también el verbo». $\mathrm{Y}$ añade: «La voz de una civilización naciente». Más aún, al comenzar su Altazor, definiéndose mediante su personaje diciendo: «Nací a los treinta y tres años, el día de la muerte de Cristo», patentiza su intención de suplantar al Verbo sacrificado en la Cruz. Como patentiza también símbolos similares al referirse en $L a$ poesía al «lenguaje del Paraíso y al lenguaje del Juicio Final». Y como se expresará también en clave crística en Pasión y muerte y en Las siete palabras del poeta, aunque aquí se decida excepcionalmente a invocar en su aflicción al Padre.

En la libertad del juicio poético, éstos son detalles de significación extrema en cuanto que la fórmula del Alfa y la Omega, referida cuatro veces en el Apocalipsis y únicamente pronunciada en este libro, es referencia subjetiva al caballero invisible que en la representación mítica se le caracteriza indirectamente por medio del «caballo blanco» que tanto impresionaba a Darío, del cual jinete afírmase que «es llamado el Verbo de Dios», y cuya profecía termina implorándole, como lo haría también Darío, «iVen!», o sea, reclamando su Advenimiento.

No porque estos dichos huidobrianos aparezcan entremezclados entre otras muchas expresiones líricas y teorías poéticas dejan de tener valor, al modo como las pepitas de oro no se devalúan por aparecer embarradas entre arenas. Dentro del cuadro general de nuestra cultura y de la poesía moderna, los mencionados son conceptos que a la luz brillan con fulgor y peso inequívocamente significativos. $Y$ en grado tal que a la calidad de precursor, que ya a su autor le habíamos reconocido, se nos incita a reconocerle por añadidura que «tiene la lengua de hierro ardiente como los profetas», según el verso con que termina su libro Tout à coup. En este aspecto, el poeta chileno se nos aparece subido en el alto palco del profetismo como una individualidad profético-precursora, a través de la cual se pronuncian algunas palabras peculiares del Verbo. 
Cuando tras referirse al Alfa y Omega anuncia en Ecuatorial la muerte del siglo, y dícese

Una mano cortada

Dejó sobre los mármoles

La línea ecuatorial recién brotada

está el poeta refiriéndose a la línea del ecuador que divide en dos los hemisferios, a la vez que predice la extinción del «siglo» en la hoguera solar. Anuncia a no dudarlo la finalización de un estado de cultura en contraste opositor a la naciente del hemisferio sur, puesto que arrebatado por el delirio sidéreo se refiere al «solo aeroplano que cantará un día en el azul».

\author{
CRUZ DEL SUR \\ SUPREMO SIGNO AVION DE CRISTO
}

He aquí una alusión a un inesperado cristianismo cósmico cuya calidad se especifica mediante los dos versos que la preceden, ciertamente estremecedores:

Ayer vi muerta entre las rosas

La amatista de Roma.

Dícese estremecedores porque Huidobro no podía imaginar que el libro del Apocalipsis, cuyos símbolos estaba utilizando o de los que Algo-Alguien se estaba sirviendo por su mediación, estuvo concebido históricamente hacia el año 96 de nuestra era, y sigue estándolo, contra la Iglesia entonces naciente de Roma, decretando su destino mortal. El veredicto que emite el "Verbo de Dios» del texto sagrado tras el despliegue de la causa profética en un lenguaje de extrañísimas figuras condena a dicha Iglesia a desaparición. Es éste un descubrimiento cultural efectuado treinta y tantos años después de publicado Ecuatorial. $Y$ se ha realizado a consecuencia de la tragedia histórica española, donde esa Iglesia, dejada de la mano de Dios, y en sacrílega representación del Crucificado del Gólgota, proclamó "guerra santa» contra su propio pueblo a la rebelión exterminante de la Bestia belicosa de muchas cabezas, y la colmó de toda especie de auxilios y bendiciones. Precisamente, esta «novísima alianza» constituye la perversidad del gran pecado que encendió en lenguaje profético contra Roma las indignaciones teológicas de Juan de Patmos.

Han transcurrido dieciocho siglos y medio de historia mediterránea 
y he aquí que en el instante crucial de ruptura entre dos mundos, y no antes ni después, el apocalíptico «Verbo de Dios» torna inteligible $e l$ «misterio» de su condena a muerte. Se pronuncia. ¿Qué género de Providencia poética es esta que declara previamente por boca de un poeta actual haber "visto» a «la amatista de Roma muerta entre las rosas» - como la madre en su ataúd «lleno de rosas vestidas de viaje» (Veo el universo..., 21)-, al tiempo que por la voz de la sangre derramada de un pueblo monstruosamente sacrificado al Moloch de los intereses mercantiles, ambas declaraciones referidas al texto del Vidente? ¿Qué dimensiones son estas que obligan a esconderse al tiempo y al espacio en un agujero negro? ¿Estamos o no en los albores del lenguaje de otra cultura de superior calidad antropológica?

Nuestro siglo eléctrico y ensimismado entre fulgurantes destellos verá surgir a Aquel que fue anunciado por Juan el de suaves cabellos.

(Rubén Darío, Pax, 1915)

No es culpa mía si el destino habla

Entre el cielo y la tierra

Hay algo grande que comienza.

¿Por qué razón?

Sólo los signos y el azar lo saben.

(Huidobro, Estrella hija de estrella, 87-89, 43-44)

Ante todo lo cual sólo cabe aquí un silencio respetuoso.

En su conjunto, los Ultimos poemas de Vicente Huidobro, epílogo de su El ciudadano del olvido, presentan alternadamente dos fisonomías dispares. Una de ellas abunda en acentos sombríos de decepción y fracaso. Corresponde al sector individualista de su personalidad fisiológica, que, no obstante las ilusiones circunstanciales que colorearon su parábola, desembocaron en las asperezas y contrariedades ineludibles. Sin embargo, el otro aspecto de sus Ultimos poemas es positivo en lo óptimo porque se encara con el porvenir, a cuyas excelencias permanece leal, sujeto. Bien hubiera querido el poeta distraer su estado de ánimo del acusado por su semblante pesimista, pero se lo impedía el destino de su propia constitución psicomental. Su individualismo de raíz y su uso del lenguaje le vedaban, según lo apuntado, el acceso a los campos colectivos de la tan deseada superhumanidad, cuyo lenguaje es de una especie imaginaria de trascendencia superior. 
En el orden verbal, la de Huidobro puede definirse como una personalidad anfibia, incapaz de desprenderse del mundo de su formación literaria ni de transponer el "Canto VII» de su Altazor, pero que incursiona en un ámbito imaginativo de gran riqueza. Aquí, como en previas ocasiones, Huidobro sigue siendo excepcional, único; de una originalidad y exuberancia de imágenes y metáforas quizá carentes de matices por lo aún grandilocuentes, pero más directas y sin comparación posible. Notablemente, su modo de ser corresponde al de un eslabón o broche cultural de doble enganche. Por uno de sus extremos mantiene a su lírica ligada en lo formal al campo gravitatorio de la experiencia europea, con que, sin embargo, no acaba de identificarse en razón de un fermento imaginativo libertario que corresponde sin duda al nuevo mundo americano de su otro extremo. Importa percatarse, aunque cueste, de que en virtud de esta forma cabalgante, la Imaginación creadora da en él testimonio de la exacta ubicación del vanguardismo de la poesía francesa, cuya voluntad profética reconocida se limitaba en nuestro siglo a girar en torno del polo negativo, de cuya atracción le era imposible desprenderse sin caer en la poesía de sentimiento social o si no en los brazos de la intrascendente.

En este orden de significados la poesía de Vicente Huidobro parece ser de importancia más compleja de lo que aparenta a primera vista. Porque en cuanto eslabón entre dos mundos, que se entremezcla, de un lado, con las savias impulsivas de la tradición francesa, señala por el otro extremo de su eslabón hacia qué punto tienden en verdad las intenciones romántico-simbolistas de la cordelada constituida por Poe, Baudelaire, Rimbaud, Mallarmé y acompañantes, sin descartar, loin de là, a cierto Víctor Hugo. En su acta de defunción de la Poesía, no se limita Huidobro a sostener que está muerta, denunciando así la, a su juicio, baja aleación creadora de Occidente, sino que confirma y concreta el oráculo de Rimbaud, que quiso, mas no pudo, desprenderse de la vieja gravitación de su cultura. "Nous allons à l'Esprit», sentenciaba en su Mauvais Sang. "C'est très certain, c'est oracle, ce que je dis... L'Esprit este proche. Hélas, l'Évangile a passé! l'Évangile! L'Évangile [...]. Ma journée est faite; je quitte l'Europe». En efecto, se fue. Pero dirigió sus pasos física y moralmente hacia el pasado en vez de orientarlos hacia el futuro -hacia América.

En contraste, Huidobro afirmará en su carta desengañada, según se ha visto: «El nuevo ser nacerá, aparecerá la nueva poesía, soplará en un gran huracán $[\ldots]$. El mundo abrirá los ojos y los hombres nacerán por segunda vez o por tercera o cuarta».

He aquí el ángulo adonde, aunque ella no se lo imagine, propende, 
a través de la experiencia, en gran parte francesa, de Huidobro el incisivo refinamiento de la poesía de Francia. Se dirige hacia el nuevo Ser, teorizado a su modo por Edgard Poe en su Eureka, libro que Baudelaire tradujo; hacia ese ángulo omnicéntrico donde situaba su esperanza mitológica el soñado "Paraíso" que el autor de los Artificiales, sumido en sus náuseas invencibles, le llenaba de lágrimas los ojos sin saber a qué otro mundo dirigirse. El Occidente, si no se estanca en sí mismo, tiende por naturaleza al Ser Universal del Nuevo Mundo, acerca de cuya calidad tampoco a la parte positiva del eslabón huidobriano, aunque él creyera en su universalidad, le era posible pronunciarse con exactitud. Por la resonancia negativa de su oquedad interna, Vicente sabía, en posición dialéctica asimilable a la de Baudelaire, el efecto que en él debía producir el Lenguaje del nuevo Ser esperado. Además sabe algo que la poesía francesa ignora. Que el nuevo Ser es y nacerá, es decir, que su presencia futura es cuestión no de creación artística individual como la suya, sino de nacimiento aparte, y aún más distintamente de aparición, de Advenimiento.

Ya aquí tórnase evidente que el apocaliptismo de Huidobro se vincula con el de su inmediato precursor, Rubén Darío, la gran voz profética de su misma orilla. Crecida esta voz en Chile, se nutrió, como después la suya propia, de la aportación simbólica de Francia, siéndole a Huidobro el magisterio de las Dilucidaciones de aquél, dirigidas «a los nuevos poetas de las Españas», decisivo para su entrega a la Poesía de haute mésure, con mayúscula. Y la ansiedad inmitigable del centroamericano, tan marcado por el apocaliptismo de Hugo, prorrumpe poderosamente desde el sumidero de sus angustias en el Canto de esperanza, que presta título al del libro en que se incluye como columna pivote, Cantos de vida y esperanza. Dicho poema es un clamor vehementemente apocalíptico. En él se implora el Advenimiento del Ser desaparecido en los comienzos de nuestra era, el mismo día de su eclipse en el que Altazor se ufana de haber nacido. En estado de posesión energuménica, Darío hace suyo el grito terminal del Apocalipsis, que es a la vez la última expresión de la revelación neotestamentaria: «iVen!» («Ven, Señor, para hacer la gloria de ti mismo»...). Trátase del Ser que, una década más tarde, el mismo Darío proclamará la inminente Venida en el poema $P a x$, que es algo así como su testamento poético-cultural.

En realidad no parece ser ningún dislate atribuible a la caprichosa extravagancia de los poetas que uno y otro, Darío y Huidobro, cada uno desde su personal situación biopoética, pongan su esperanza en el Advenimiento del Ser. Aunque sea éste un tema desechado por la gran mayoría, si no por la casi totalidad de los actualmente vivos, trátase de la creencia 
fundamental de nuestra Cultura, que desde hace lapsos y lapsos tiene depositada la esperanza de su justificación colectiva en el futuro. ¿De dónde proviene la idea de la superhumanidad? Por su obcecado individualismo psicosomático, nuestra época mantiene al Ser relegado a la conciencia pensante de cada individuo particular, con total eclipse del Ser de la sustancia colectiva. Y, naturalmente, a la psicología de los individuos en sí, reprimida y modalizada por las cuestiones y apasionamientos de su existencia inmediata, no le despierta el menor interés lo que puede ocurrir en tiempos que no les conciernen por lo distantes que están de los personales suyos. Mas en los casos de personificación profética, la realidad psicológica es muy distinta. En ellos puede sentirse la necesidad de justificación en el futuro de aquello que en su constitución psíquica les es en cierta manera como actual, mas no en cuanto individuos particulares que son, sino como propio de la especie. Identificados con lo esencial del Lenguaje, los niveles de su conciencia han de ser otros. El futuro es interés del Destino, en el que sienten ser su afán ético-estético. Darío suspira por el Advenimiento prometido en las Escrituras, con angustia personal intensa, con urgencias de salvación. Huidobro lo encara desde su taller imaginativo, donde no le ha sido posible producir las creaciones decisivas que anhelaba, sino sólo anunciar como precursor el Ser nuevo de la Cultura nueva. En lo que coincide con Darío. Ya no se resiste a aceptar que ese Alguien pueda ser ajeno al sujeto de su propia experiencia. Es otro. Es el correspondiente al otro Lenguaje a que aspiraba y perseguia el Simbolismo en la penetración poética de avanzada. Aunque no lo explicite, es el mismo Ser de Rimbaud y Mallarmé. Je est un autre.

La gran novedad que por Vallejo se introduce en este esquema panorámico ofrece aspectos que es obligado apuntar. $10^{\circ}$, Vallejo no espera el Advenimiento del Verbo, con el que se identifica en ocasiones («Acaba de pasar el que vendrá... a sentarse a mi triple desarrollo»), inclusive en su tratamiento peculiarísimo del Lenguaje y su denuncia del habla que juzga «babilónica». 2. ${ }^{\circ}$, Ello no obstante exhorta a salir al encuentro de su símbolo en una viandanza progresiva que no es de carácter individual, sino de sustancia colectiva y aun universal. $3 .^{\circ}$, La eficacia de su talismán reside en el Amor conjunto, que, como fundente, genera la unánime Unidad. ( $\mathrm{O}$ Oh lo que es Uno for todos, / Amor contra el espacio y contra el tiempo»). 4..$^{\circ}$, Su carácter más propio corresponde al drama histórico que le llevó a rendir su Espíritu en el Cáliz de España, la madre de su Verbo.

Pues bien: unidos Huidobro y Vallejo, rostros al fin de un solo fenómeno de vanguardia, constituyen en nuestro idioma, pese a sus diferencias, la gran profecía poética de la primera mitad de nuestro siglo de 
ruptura. Tan distinta es su Poesía de la Eurohispana, que para caracterizarlas debidamente se ha de recurrir al esquema formulado por Huidobro acerca de los dos tipos humanos que denomina Hombre Espejo y Hombre-Dios. La poesía Eurohispana, que, como sujeta a la tradición, no entiende de crear, corresponde evidentemente al primero. El poeta refleja el mundo circundante, lo mismo en temas que en imágnes, sentimientos y problemas derivados. No se aparta de los niveles de costumbre, reproduciendo el contenido del tiempo e interesado en la depuración y encanto a la usanza antigua del lenguaje común. Salta a la vista su diferencia esencial con el arte ultrapirenaico de la pintura practicada por Picasso y compañía.

Frente a ellos, Huidobro y Vallejo, retratados ambos por Picasso, quiebran como esos pintores las estructuras circunstanciales, apelando al absurdo para ocuparse no de lo que existe en su momento, sino, aunque en niveles distintos, de lo que sienten que será. Se trata de crearlo en la actitud intelectual de Huidobro; de serlo en la vivencial de Vallejo, quien por lo mismo estaba predestinado a morir en la Cruz. En la Cruz de España, a quien suplica que aparte de él la amargura de su Cáliz, aunque se sabe en su corazón de sobra que ha de apurarlo hasta el final. En el árbol de la Cultura en que brota la yema de Vallejo se halla presente el Verbo como lo ha estado en sus reacciones apasionadas y en el tratamiento del lenguaje, que no poco se aproxima al presunto segundo lenguaje y en el renuevo conforme a los moldes actuales del sacro arquetipo. Hoy no se recluye en las aulas académicas ni se exhibe en los escenarios, sino que transita por las calles en compañía de algunos poetas la soberana Ontología.

Mas si de la figura de Vallejo puede afirmarse que es el exponente de un espíritu neocristiano, de Huidobro, iniciado como aquél en la ideología superhumana de Nietzsche, por muy anticristianos que suenen a veces sus desplantes, obligado es convenir en que su anticristianismo no es tal en realidad, sino anticatolicismo romano. Su anticristianismo es de ocasión, según lo delatan Las siete palabras del poeta, emitidas desde la Cruz, como Vallejo, dirigiéndose al Padre en cuanto Hijo. Ambos coinciden también en ser antiliteralistas, es decir, repudian la letra que mata en favor del Espíritu que vivifica. Si Huidobro no es capaz de desprenderse de su estado equívoco, se debe a que se sitúa en las inmediaciones de la personificación racional del Verbo. Se encuentra así amarrado a su egoísmo personal. Vallejo, en cambio, si piensa en sí, es porque está pensando y sintiendo en todos, colectividad de la que no puede desgajarse integrado como está a su sustancia.

Lo extraordinario y en verdad portentoso es que unidos Huidobro y 
Vallejo - con el respaldo de Darío- constituyen en dos niveles complementarios la profecía trascendental de la Poesía de Hispanoamérica en cuanto reveladora del sentido de su futuro, que es a la vez el del planeta. $Y$ que esto lleva consigo la extinción, no dictaminada por ellos, sino a través de ellos por el Destino Creador, de la institucionalizada Iglesia medieval de Roma. Se produce ello en virtud de la aparición mental del Ser que la destituye, abriendo en su lugar los vastos horizontes imaginativos del corazón y de la cabeza del Hombre específico. Cumplido el ciclo de la creación histórica, sobreviene la implantación ubicua del Verbo absoluto, con el que los amantes de la Verdad puedan comunicarse hasta su conjunta identificación genérica, estableciendo aquellas estructuras socioculturales aludidas en el gran Mito de la geométricamente simbólica Nueva Jerusalén o Nueva Ciudad de la Paz. He aquí el cuerpo físico del auténtico Nuevo Adán, «Nueva Tierra» paradisíaca, donde el Ser divino es inmanente con detrimento total para la Muerte en cuanto entidad metafísica radicada en el individualismo corpóreo. Y ello no se reduce al Ser de la Cultura Hispánica y su Nuevo Mundo Colombino, sino que, por tratarse del Ser Humano en plenitud, incluye al planeta en su universo. Y además establece, como una de las grandes avenidas de acceso de la Cultura Occidental al centro del mismo, el testimonio profético de la poesía francesa.

Se trata, en definitiva, de la existencia de un sistema simbólico de presentimientos, previsiones y gestas vividas independiente de la estrecha concatenación racional de tiempo, espacio y causalidad, que proviene de muy lejos y se dirige también a extremas lejanías. Y se trata del sentido universal de América del Sur, según lo señala la configuración compuesta al menos por Dante Alighieri; por Cristóbal Colón, que descubrió la «nueva tierra del Apocalypse»; tal vez por Goethe, y con seguridad por Rubén Darío, César Vallejo y Vicente Huidobro, que son, no por caprichos personales aislados, sino por los hados Verbales del Ser creador, los artejos sintácticos de una revelación llamada, según parece, a servir de fundamento con referencia al Verbo de Dios del Apocalipsis a una auténtica Cultura universal, nueva. Por cierto, no se trata en ella de los motivos cesáreos, cuantitativos, que se contorsionan en los conflictos sociointestinales, que, naturalmente, han de ser resueltos por sus propias vías ontológicas. Se trata del Ser; de la transfiguración de la Conciencia humana establecida en el más allá de la Muerte.

Y se relaciona con España y su lenguaje, con la trascendencia mítica de la historia mítica de la tragedia española, que ha desencadenado una catástrofe de sustancia trascendental incubada pausadamente desde largos siglos. 
Si se estimase históricamente real lo expuesto con motivo de la Poesía clave y sublime de Huidobro, que establece una solución de continuidad entre el Occidente y el Universo terráqueo, habria que sacar en limpio, al campo abierto de la superrazón, que hoy se está viviendo en nuestras latitudes un proceso de mutación genérica en el orden del Espíritu, que determina la constitución de una Cultura Nueva, de Nuevo Mundo, en funcićn de los valores esenciales con sede inicial en América Latina. Su esquema de derivación se modaliza así:

\author{
Más allá de Roma \\ Rubén Darío \\ Vicente Huidobro \\ Neo-cristianismo \\ César Vallejo \\ Espiritumanidad
}

Aquilatando (de águila), puede considerarse que, confinado por naturaleza al orden de las figuras sensuales, Huidobro es en cierto modo precursor de Vallejo; precursor no en los aspectos literales y literarios (cómo se hubiera él indignado ante semejante desatino), sino del Espíritu de lo que significa la experiencia reveladora del Poeta nacido en los altos Andes del Perú.

De todos modos, con Huidobro y con Vallejo la Poesía en lengua castellana se demuestra situada en un nivel sublime, ajeno al cultivado en el área peninsular, aun recordando la portentosa corroboración del Grito hacia Roma de Federico García Lorca, proféticamente concebido en el Nuevo Mundo. La conciencia de nuestra Cultura se descuelga por los ramales de sus experiencias místico-míticas hasta su primera y última raíz. Ambos poetas de América del Sur son los portavoces heráldicos de los compromisos del Mundo Nuevo.

Uno y otro, aunque en formas distintas, dan testimonio de la presencia más o menos disimulada del Verbo en el espacio que media entre el Alfa y la Omega de la profecía referida a América desde el día de su descubrimiento bajo el escudo apocalíptico de los Reyes Católicos y las cartas de Colón. Fin y Principio. Por no ser un objeto material captable por los sentidos, sabido es desde siempre que al Espíritu no se le ve. Mas sí puede percibirse indirectamente la presencia de su voluntad al modo como se percibe el paso del viento en la agitación y sonido del follaje. En Huidobro y Vallejo se acusa su presencia en este momento de ruptura en que su Palabra creadora es necesaria para facilitar el tránsito de mundo a mundo. Porque el Ser, sabido es también desde antiguo, ninediante hálito prestado, a su hora se deja oír. Precisamente lo caracte- 
rístico del Verbo, o sea, de la esencia de nuestra facultad comunicativa en todo orden de relaciones, inclusive en el reservado para el Absoluto, es hablar. "La poesía es fundación del ser por la palabra», dejó dicho Hölderlin, como lo repiten los filósofos.

Así, en este instante crítico se le oye al Destino en la voz individual de Huidobro repudiar en bloque el contenido de la época, a quien dedica el poema «Edad negra» con que termina su Antología, donde se colectan todas las nigromancias imaginables. Entre ellas no es de creer que se excluyan las de algunos de sus viejos penates, Baudelaire, Lautréamont, Surrealistas... y de cuantos se solazan en los lodazales bituminosos de la desesperación. Tras abominar de toda esa turbamulta de nocturnidades, se torna Vicente hacia los nuevos poetas de las Españas para recomendarles con espíritu testamentario que inicien su marcha por otras vías. Dice su verso final:

Guárdate, niño, de seguir tal ruta.

En tanto que complementariamente se le oye a Vallejo dirigir las últimas palabras de su mensaje revelador a las nuevas generaciones de habla española, cargando el acento en la condición colectiva del ser humano, que, si bien se escudriña, se proyecta al más allá de la Muerte:

$$
\begin{aligned}
& \text { si la madre } \\
& \text { España cae -digo, es un decir- } \\
& \text { salid, niños del mundo: id a buscarla! }
\end{aligned}
$$

Vayamos.

\section{«POST SCRIPTUM»}

Terminado este estudio, me encuentro al remover la correspondencia de Vicente Huidobro, a fin de precisar algunas fechas, con el siguiente «pneumático» totalmente olvidado por mí desde hace cincuenta años y que leo con asombro:

Hoy viernes 5 (abril 1929)

Querido Juan. Te espero esta tarde a las 7 para que vengas a comer a casa pues hoy es San Vicente Huidobro.

Trae algunos poemas que leerás en honor de este gran Santo-El Angel del Apocalipsis.

Saludos.-V. HuIdobro.

JUAN LARREA

Universidad Nacional de Córdoba, Argentina. 
